University of Nebraska - Lincoln

DigitalCommons@University of Nebraska - Lincoln

Copyright, Fair Use, Scholarly Communication, etc.

$1-2021$

\title{
Academic Libraries and Open Access Books in Europe: A Landscape Study
}

Agata Morka

Open Book Publishers

Rupert Gatti

Open Book Publishers

Follow this and additional works at: https://digitalcommons.unl.edu/scholcom

Part of the Intellectual Property Law Commons, Scholarly Communication Commons, and the Scholarly Publishing Commons

Morka, Agata and Gatti, Rupert, "Academic Libraries and Open Access Books in Europe: A Landscape Study" (2021). Copyright, Fair Use, Scholarly Communication, etc.. 186.

https://digitalcommons.unl.edu/scholcom/186

This Article is brought to you for free and open access by the Libraries at University of Nebraska-Lincoln at DigitalCommons@University of Nebraska - Lincoln. It has been accepted for inclusion in Copyright, Fair Use, Scholarly Communication, etc. by an authorized administrator of DigitalCommons@University of Nebraska Lincoln. 


\section{OPERAS}

open scholarly communication in the european research area for social sciences and humanities

\section{Academic Libraries and Open Access Books in Europe A Landscape Study}

By Agata Morka and Rupert Gatti 


\section{OPERAS}

open scholarly communication in the european research area for social sciences and humanities

\section{copim}

This report has been created as a result of cooperation between the OPERAS-P and COPIM projects. They share similar interests in exploring innovative revenue models for open access books.

COPIM is supported by the Research England Development Fund (REDFund), and by Arcadia, a charitable fund of Lisbet Rausing and Peter Baldwin.

\section{OPERAS-P}

This project has received funding from the European Union's Horizon 2020 research and innovation programme under grant agreement No 871069

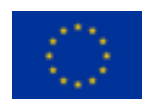

https://doi.org/10.5281/zenodo.4483773 Attribution 4.0 International (CC BY 4.0)

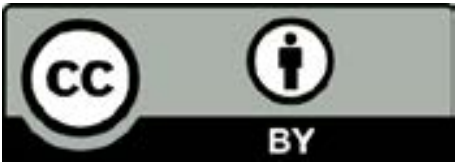




\section{CONTENTS}

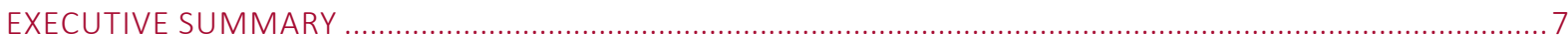

ACADEMIC LIBRARIES AND OA BOOKS IN EUROPE (OVERVIEW TABLE) ...................................................

INTRODUCTION

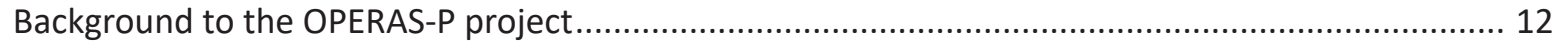

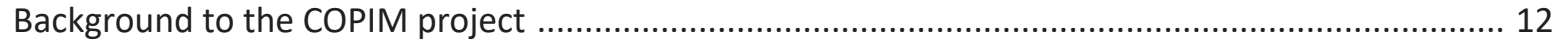

Aims

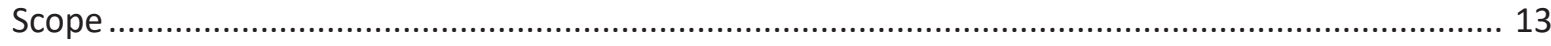

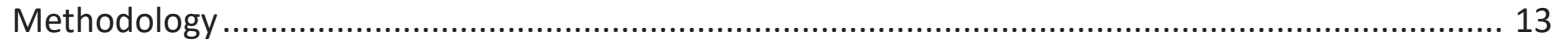

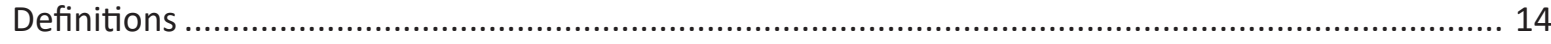

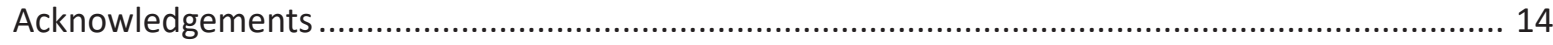

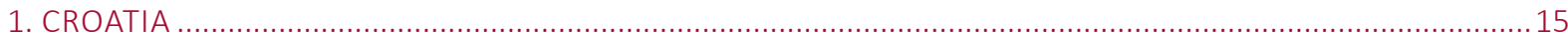

1.1 General library system for e-content and OA publications ..................................................... 15

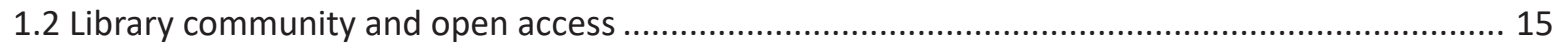

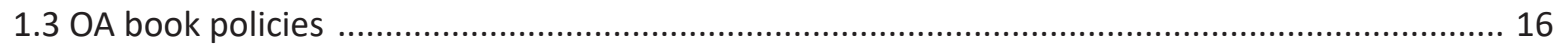

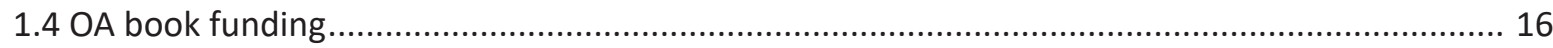

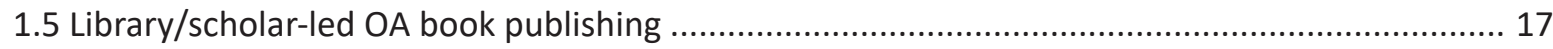

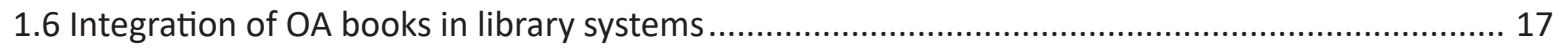

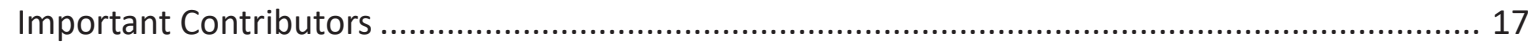

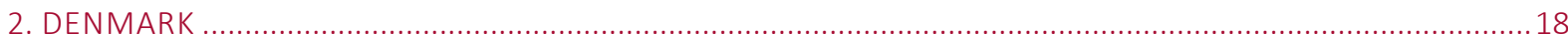

2.1 General library system for e-content and OA publications...................................................... 18

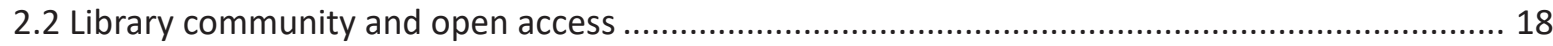

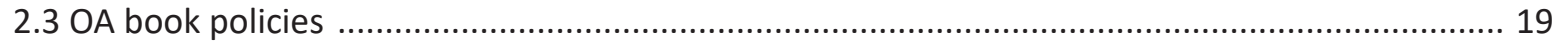

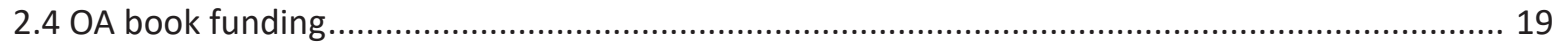

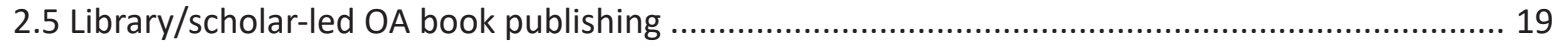

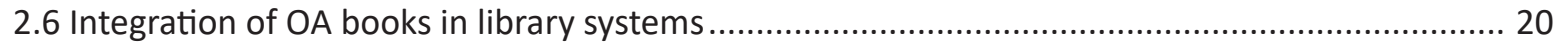

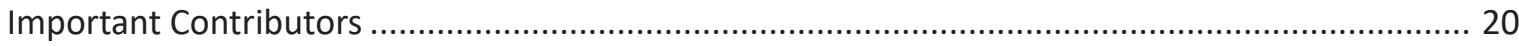

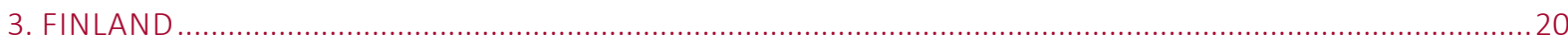

3.1 General library system for e-content and OA publications...................................................... 20

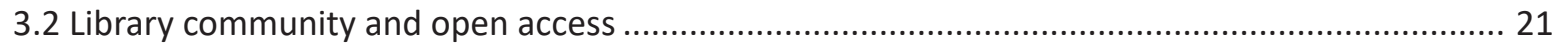

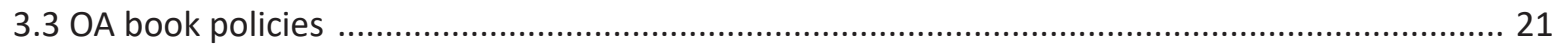

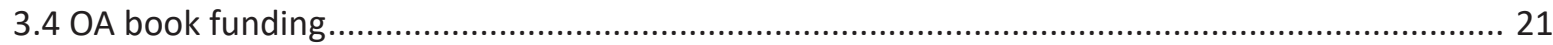

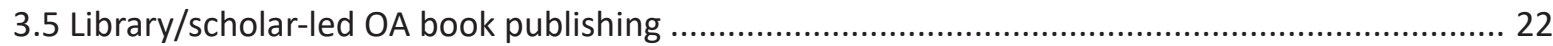

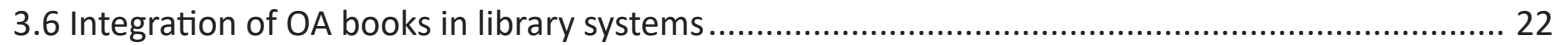


4. FRANCE

4.1 General library system for e-content and OA publications............................................... 23

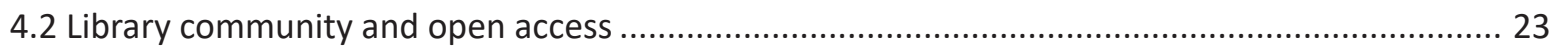

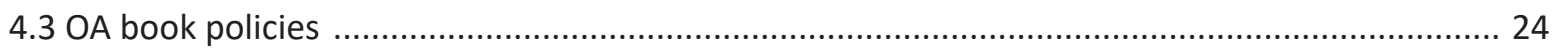

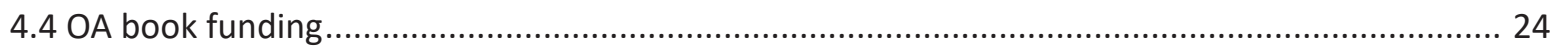

4.5 Library/scholar-led OA book publishing ..................................................................... 24

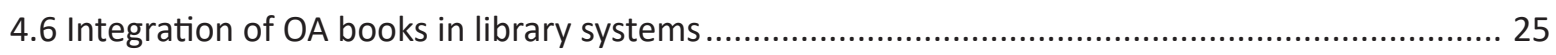

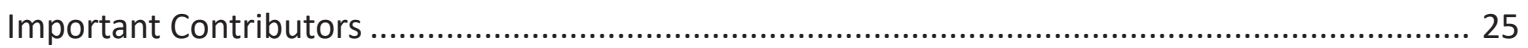

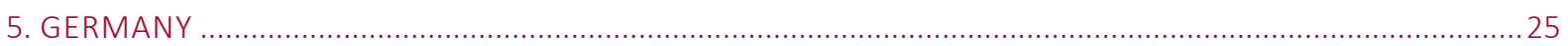

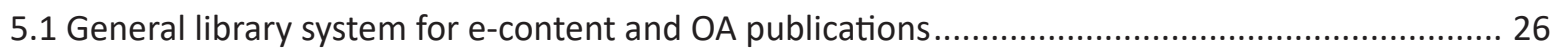

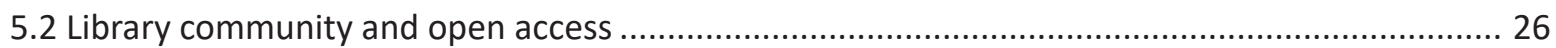

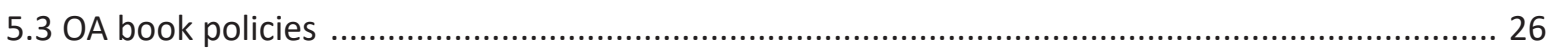

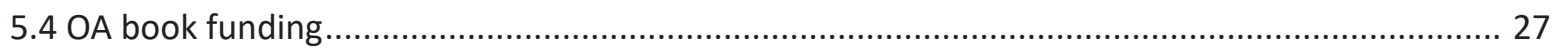

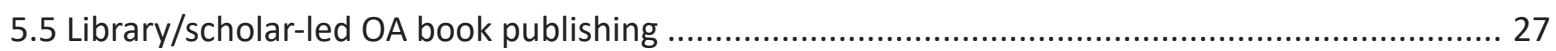

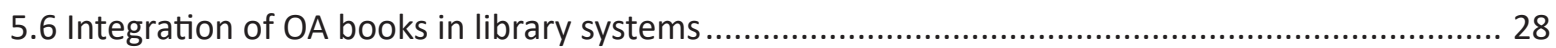

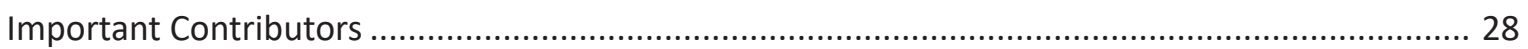

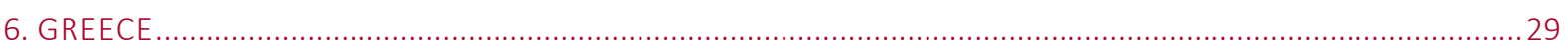

6.1 General library system for e-content and OA publications ............................................... 29

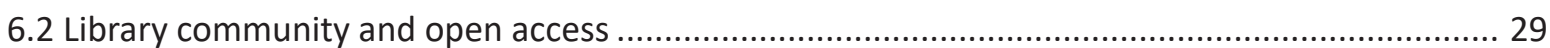

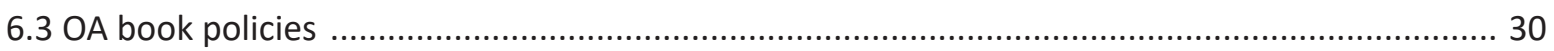

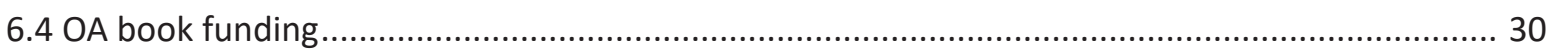

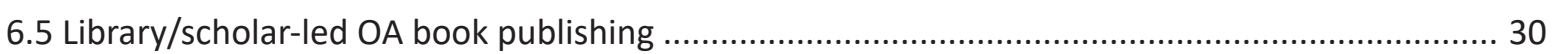

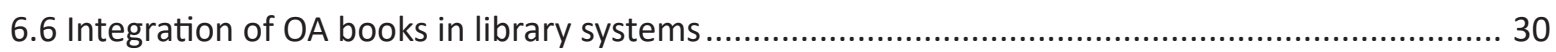

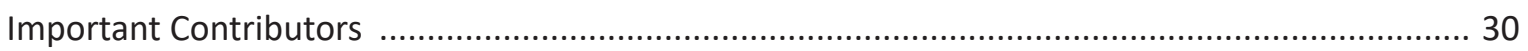

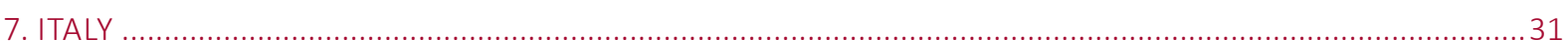

7.1 General library system for e-content and OA publications .............................................. 31

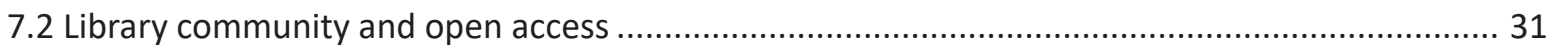

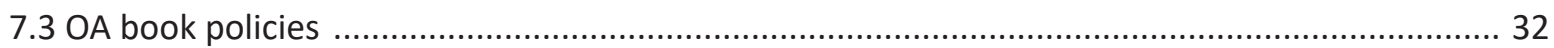

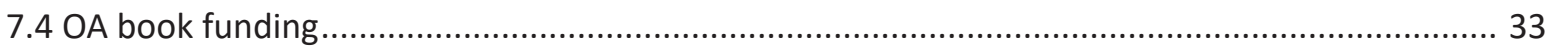

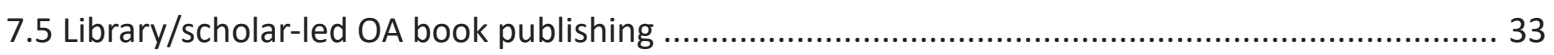

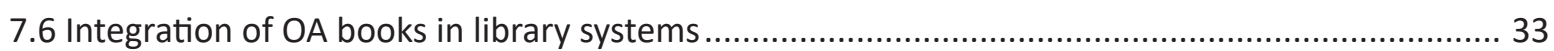

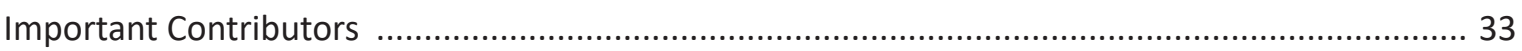


8.1 General library system for e-content and OA publications ....................................................... 34

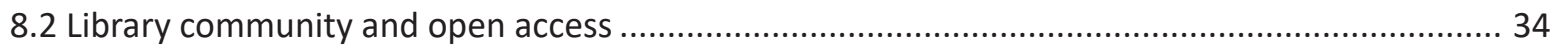

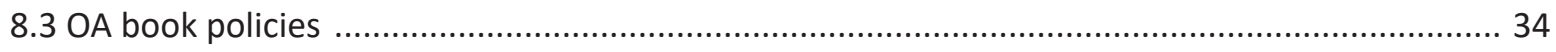

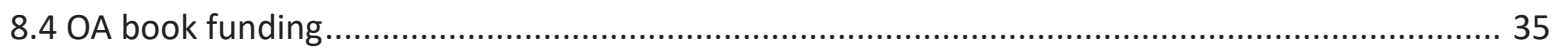

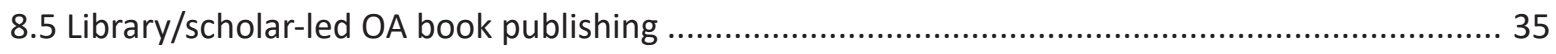

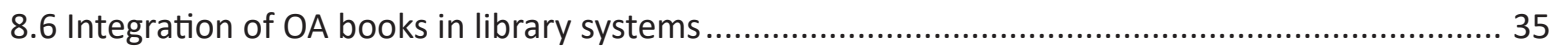

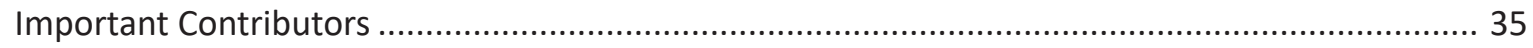

9. POLAND

9.1 General library system for e-content and OA publications ....................................................... 36

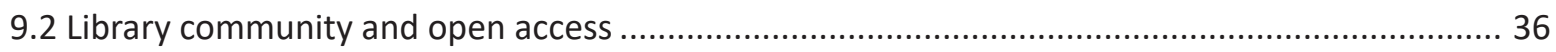

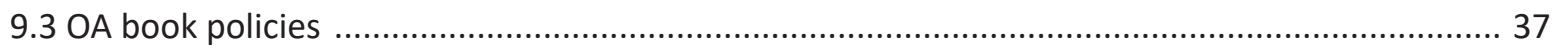

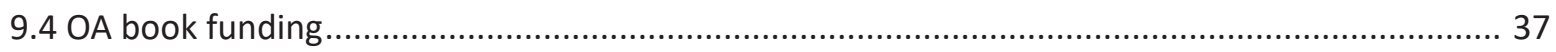

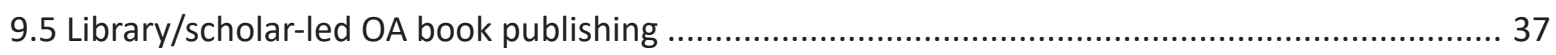

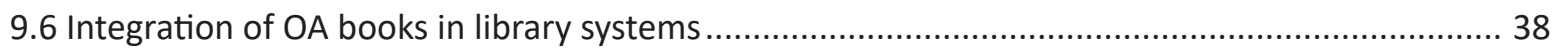

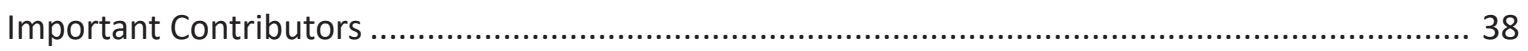

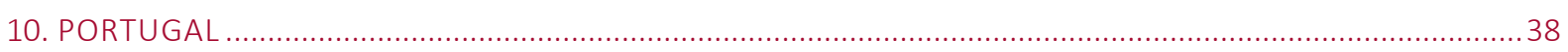

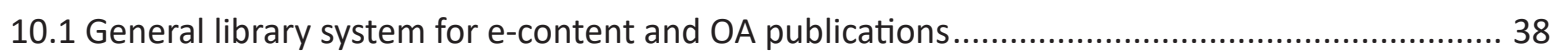

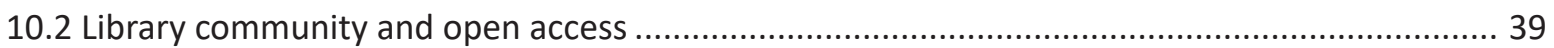

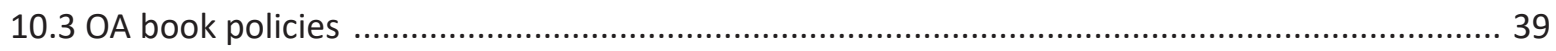

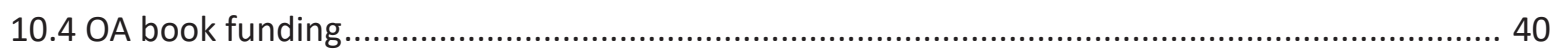

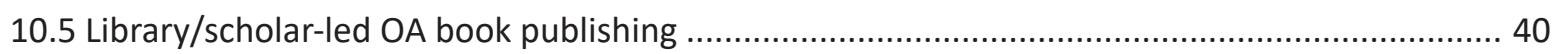

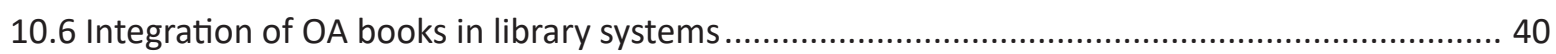

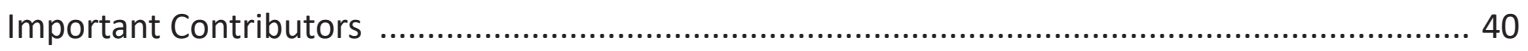

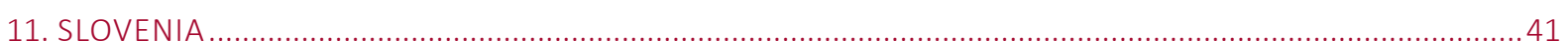

11.1 General library system for e-content and OA publications ....................................................... 41

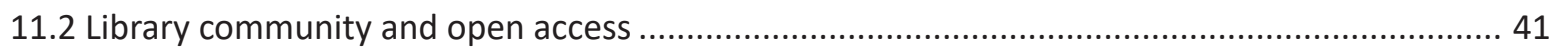

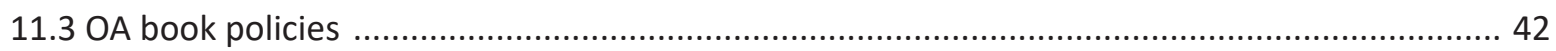

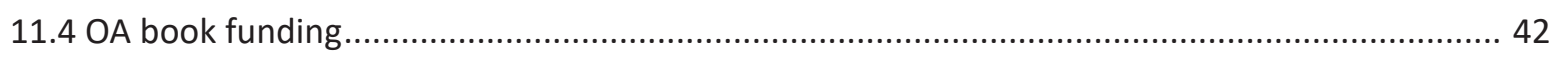

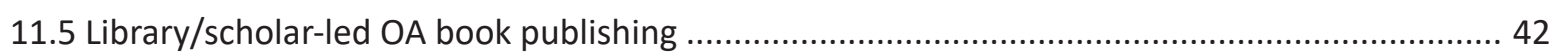

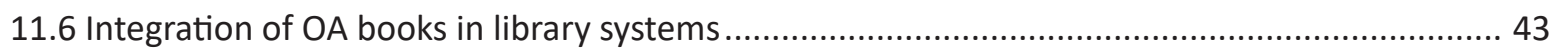

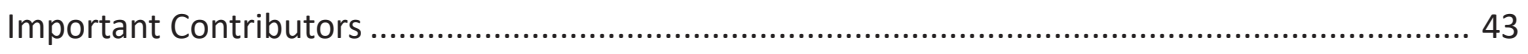

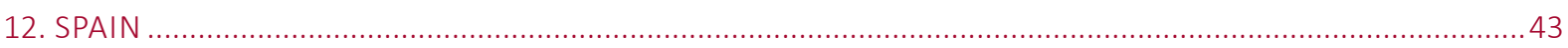

12.1 General library system for e-content and OA publications ................................................... 43 
12.2 Library community and open access

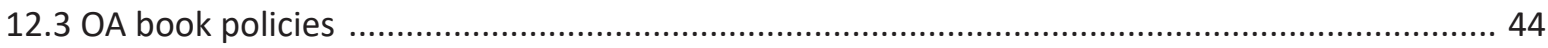

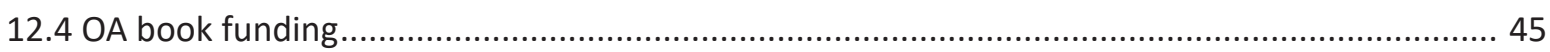

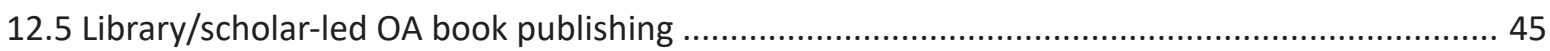

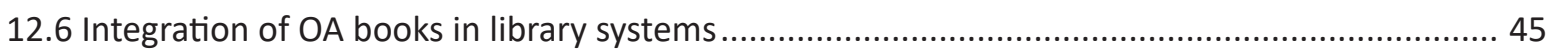

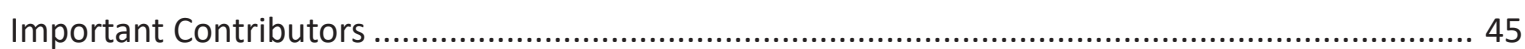

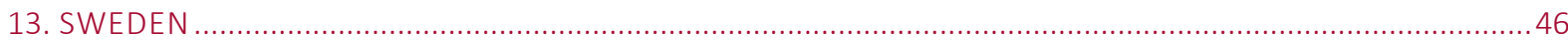

13.1 General library system for e-content and OA publications............................................ 46

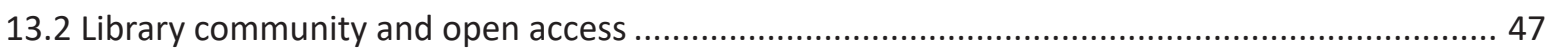

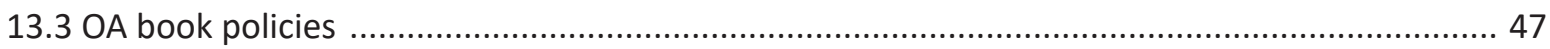

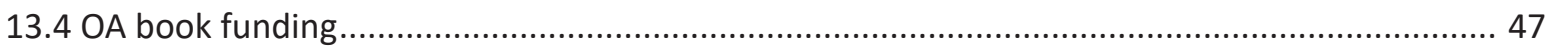

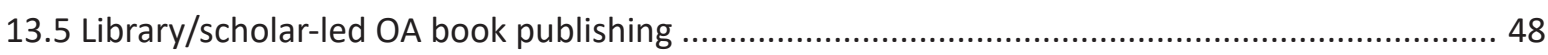

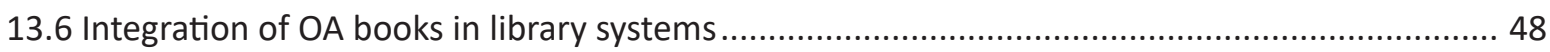

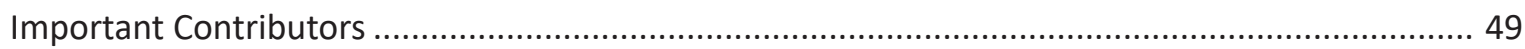

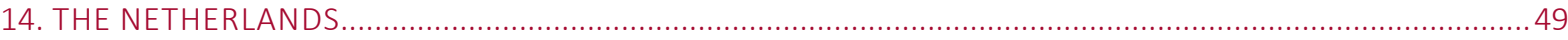

14.1 General library system for e-content and OA publications............................................ 50

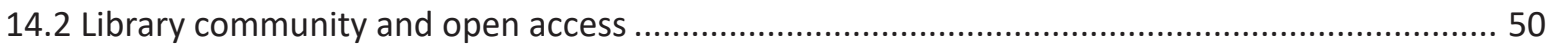

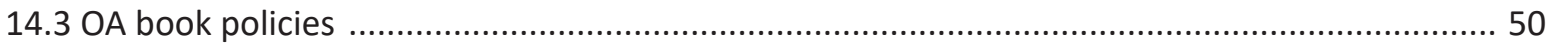

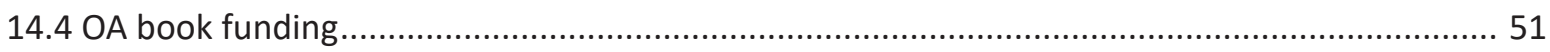

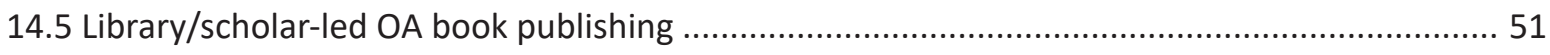

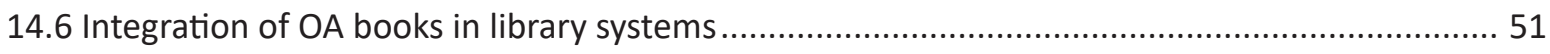

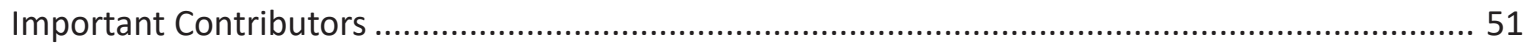

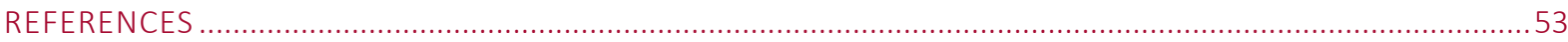

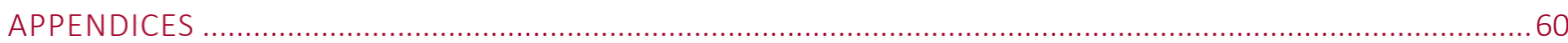

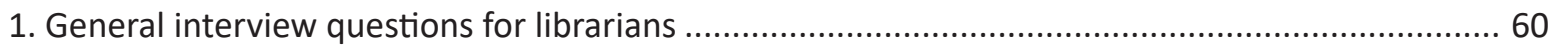

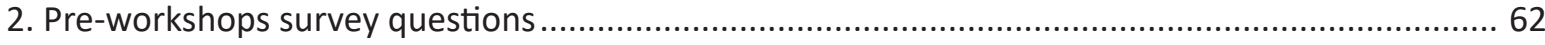




\section{EXECUTIVE SUMMARY}

The last fifteen years have witnessed the emergence of a new role for academic libraries. Besides fulfilling their fundamental task of providing access to knowledge, besides being called everything from temples of knowledge to disturbing heterotopias, libraries have become one of the crucial stakeholders in the open access book publishing space. They act as funders for OA book fees, they support collaborative funding schemes, and sometimes they assume the role of publishers themselves.

In an attempt to create a sustainable publishing environment, in which OA books could blossom, it is therefore necessary to gain a sound understanding of how academic libraries work, how they deal with open access initiatives, and what challenges they encounter. These questions remain at the very core of this report.

The landscape painted in this report is by no means exhaustive; there are many more countries in the European community, other than the fourteen we have looked at, that need further investigating. The sample that we have taken under closer inspection proved to be a lively and diverse organism that escapes any easy overarching classifications. In order to better understand the role of academic and research libraries in Europe regarding open access books, we have looked at several crucial aspects that would help us both identify common threads and pinpoint regional particularities. We have examined each country according to the following areas of interest: 1 . general characteristics of library systems for e-content and OA publications, 2. library community and open access, 3. OA book policies, 4. OA book funding, 5. library/scholar-led OA book publishing initiatives, and 6 . integration of OA books in library systems.

A general look at academic libraries' systems in the chosen fourteen European countries has revealed certain polarities. While in some countries libraries enjoy relative autonomy in their decision-making processes and budget spending (e.g. Germany, Norway), in others they rely heavily on centralised systems, where Ministries of Education play a decisive role in the state budget allocations per institution and collection building on a national, rather than institutional, level (e.g. Croatia, Poland).

It is a common practice across Europe for libraries to come together and form consortia, which represent the collective interests of participating libraries, especially when it comes to discussing deals with major publishers and negotiating terms of access to the e-content. Such organisms can develop on a regional (e.g. Spanish regional consortia), national (e.g. Couperin in France) or even transnational level (GASCO for German speaking countries, including Germany, Austria, and Switzerland).

The European library community is characterised by the presence of numerous library associations, which treat open access as one of the critical points of discussion. On the one hand, well-established librarian networks with long history (e.g. the Italian Libraries Asso-ciation, established in the 1930s, or BAD, the Portuguese Association of Libraries in Archives, established in 1973) have created special interest groups to deal with OA-specific topics. On the other hand, new organisations united around the issues of open science are emerging in the European library community (e.g. ENABLE! in Germany). The abundance of these initiatives across Europe shows the scale and importance of library engagement in open access publishing practices.

OA book policies are slowly being introduced across Europe. Only three out of the fourteen countries we looked at have introduced national OA policies that include books (France, Poland, the Netherlands). Slovenia, in its OA national strategy, encourages - yet does not mandate - OA for books. 
Institutional OA mandates exist in all investigated countries, with some also having funder-specific OA requirements (e.g. NWO, the Dutch Research Council).

OA book-specific funding remains a rarity in the countries we have looked at. Out of the fourteen cases, only four countries (Germany, the Netherlands, Finland, and Norway) have OA book-dedicated funds, some on the national, others on the institutional or funder's level. The presence of such funds in these four countries does not come as a surprise: they are also among the European pioneers of the open access movement. In the remaining ten countries OA book publications are most commonly funded through researchers' grants, with a pool of the grant money allocated towards OA publication fees.

Library or scholar-led OA book publishing initiatives have not (yet) gained momentum in Europe. While there are several emerging projects involving libraries, in most cases they are not large in scale (e.g. FF Open Press at the University of Zagreb). Among the pioneers of innovative OA book publishing models are Germany, Denmark, Finland, and Sweden. There are also few examples of projects partially subsidised by the national funders (OA books from the Faculty of Arts at the University of Ljubljana, Slovenia and the Kallipos+ project in Greece). In the majority of the investigated countries, however, such initiatives do not exist.

When it comes to integration of the e-content with library catalogues, libraries across Europe rely on the aggregators they choose to partner with; therefore, the presence - or lack thereof - of OA books in local catalogues depends on how well they are covered by these partners. Since the OA book coverage by major aggregators tends to be patchy (a concern expressed by several of the interviewed librarians), in many cases, where resources allow, OA book records are introduced to local catalogues manually. The DOAB is mentioned by librarians as the source of metadata for OA books that they use and often link to on the libraries' websites.

Findings of this report suggest that there is potential to create an EU-wide consortia funding model for OA books. There is an incontestable interest in OA books in general coming from the European academic library community. Despite this enthusiasm, however, one needs to be mindful that a project of such scale will be faced with numerous challenges.

There are deep discrepancies between the members of the European Community when it comes to dealing with open access issues. In the Nordic countries, Germany and the Netherlands it has become one of the pivotal aspects of scholarly communication; institutions are supportive, and there are funding schemes allowing libraries to invest in OA book publishing initiatives. Other regions still struggle with full integration of OA publications in their library ecosystems: there is insufficient funding, not enough human resources, little autonomy of decision-making on an institutional level and hence little room for experimentation.

After having examined the European academic library landscape, it seems clear that it will be difficult, if not simply impossible, to try to find a single model for an EU-wide collaborative funding scheme for OA books. Since, however, there are several regional trends and similarities between the examined countries, it would seem prudent to gather them into clusters based on these similarities and create a variety of models that would work for centralised and decentralised systems, and for both OA veterans and novices. 


\section{ACADEMIC LIBRARIES AND OA BOOKS IN EUROPE (OVERVIEW TABLE)}

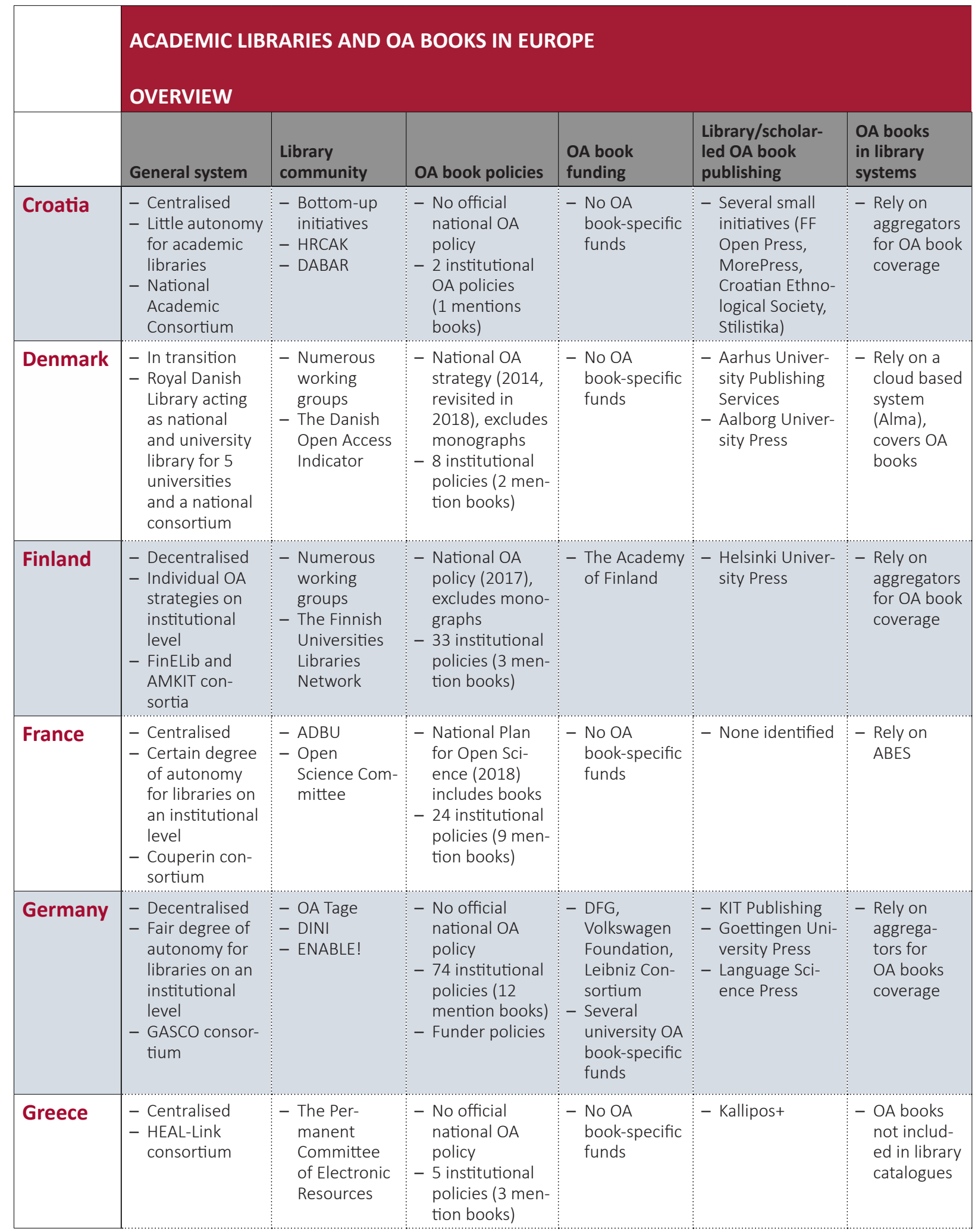




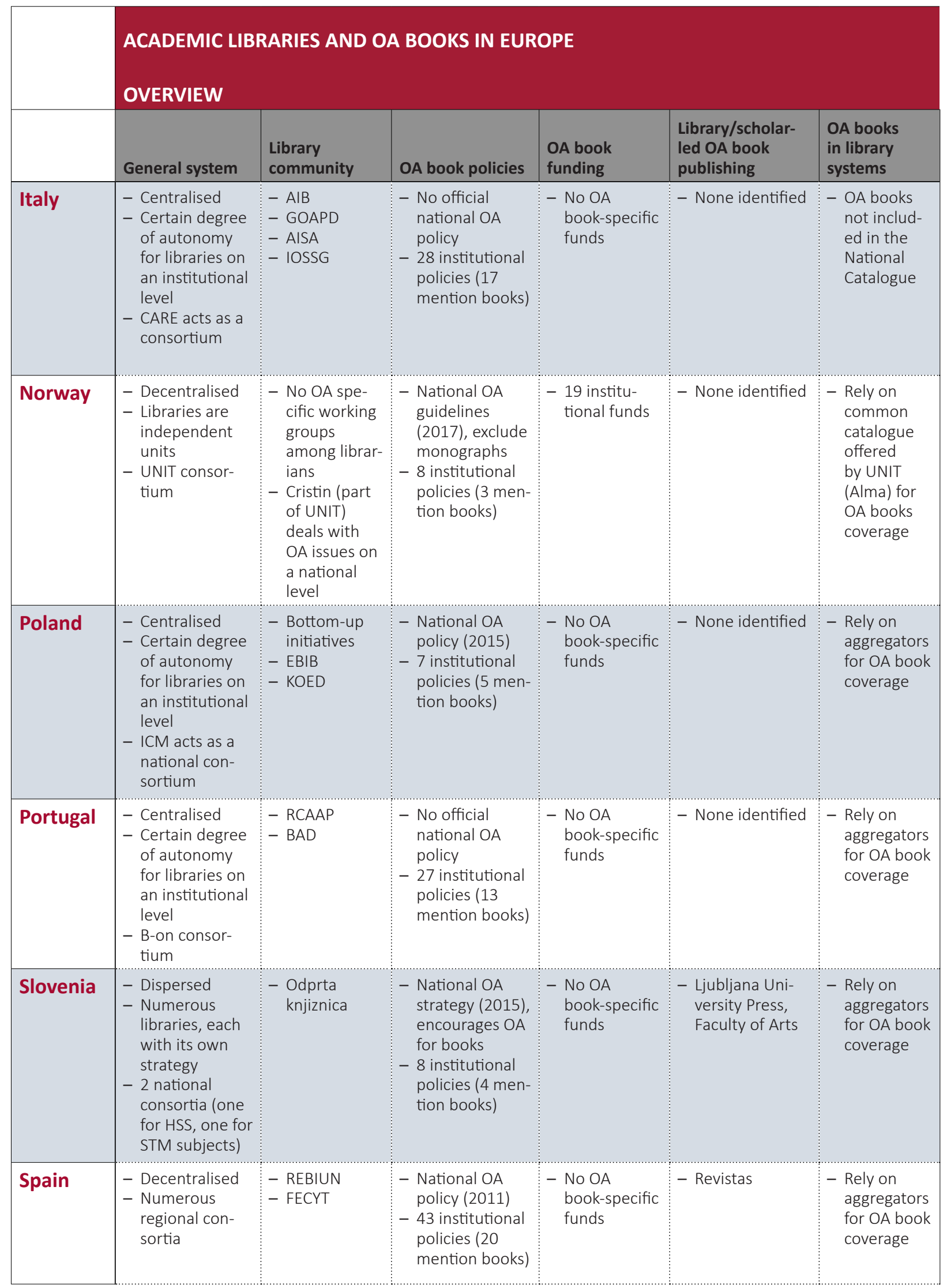




\begin{tabular}{|c|c|c|c|c|c|c|}
\hline & \multicolumn{6}{|c|}{ ACADEMIC LIBRARIES AND OA BOOKS IN EUROPE } \\
\hline & General system & $\begin{array}{l}\text { Library } \\
\text { community }\end{array}$ & OA book policies & $\begin{array}{l}\text { OA book } \\
\text { funding }\end{array}$ & $\begin{array}{l}\text { Library/scholar- } \\
\text { led OA book } \\
\text { publishing }\end{array}$ & $\begin{array}{l}\text { OA books } \\
\text { in library } \\
\text { systems }\end{array}$ \\
\hline Sweden & $\begin{array}{l}\text { - Decentralised } \\
\text { - Libraries vary in } \\
\text { size, resources } \\
\text { and funding } \\
\text { - The National } \\
\text { Library of } \\
\text { Sweden acts } \\
\text { as a national } \\
\text { contact point } \\
\text { for OA issues } \\
\text { - Bibsam consor- } \\
\text { tium }\end{array}$ & $\begin{array}{l}\text { - The Swedish } \\
\text { Library As- } \\
\text { sociation }\end{array}$ & $\begin{array}{l}\text { - National Guide- } \\
\text { lines for Open } \\
\text { Access include } \\
\text { monographs } \\
12 \text { institutional } \\
\text { policies ( } 2 \text { men- } \\
\text { tion books) }\end{array}$ & $\begin{array}{l}\text { - No OA } \\
\text { book-specific } \\
\text { funds }\end{array}$ & $\begin{array}{l}\text { - Stockholm Uni- } \\
\text { versity Press } \\
\text { - Kriterium }\end{array}$ & $\begin{array}{l}\text { - Rely on } \\
\text { aggregators } \\
\text { for OA book } \\
\text { coverage }\end{array}$ \\
\hline $\begin{array}{l}\text { The } \\
\text { Nether- } \\
\text { lands }\end{array}$ & $\begin{array}{l}\text { - Fair degree of } \\
\text { autonomy for } \\
\text { libraries on an } \\
\text { institutional } \\
\text { level } \\
\text { - UKB consor- } \\
\text { tium }\end{array}$ & $\begin{array}{l}\text { - UKB Open } \\
\text { Access Work- } \\
\text { ing Group } \\
\text { - National Plat- } \\
\text { form Open } \\
\text { Science }\end{array}$ & $\begin{array}{l}\text { - National Open } \\
\text { Science Plan } \\
\text { (2017), in- } \\
\text { cludes books } \\
\text { - } 11 \text { institutional } \\
\text { policies ( } 4 \text { men- } \\
\text { tion books) }\end{array}$ & $\begin{array}{l}\text { - NWO } \\
\text { - Institutional } \\
\text { funds }\end{array}$ & - None identified & $\begin{array}{l}\text { - Rely on } \\
\text { aggregators } \\
\text { for OA book } \\
\text { coverage }\end{array}$ \\
\hline
\end{tabular}




\section{INTRODUCTION}

This report has been created as a result of cooperation between the OPERAS-P and COPIM projects. They share similar interests in exploring innovative revenue models for open access books.

As part of the Work Package 6 at OPERAS-P we are investigating existing and emerging business models that depart from the Book Processing Charges scheme and often involve libraries in the publishing processes.

As part of the Work Package 2 at COPIM we are creating a model based on cooperative library funding for OA books.

\section{BACKGROUND TO THE OPERAS-P PROJECT}

The OPERAS-P project supports the OPERAS Research Infrastructure by furthering the development of the infrastructure in view of achieving the necessary scientific, technical and community maturity.

The key objectives of the OPERAS-P project are the following:

- Produce the necessary documentation defining OPERAS' strategy and implementation to support the ESFRI application.

- Support the preparation phase of the infrastructure by implementing a legal framework, a governance and support the implementation and coordination of services.

- Prepare a long-term, evidence-based strategy for the development of the infrastructure and its services

- Ensure outreach and advocacy for open scholarly communication in social sciences and humanities, developing a communication strategy on the infrastructure and supporting the expansion of the consortium, and enhancing innovation for the future of scholarly communication practices in social sciences and humanities.

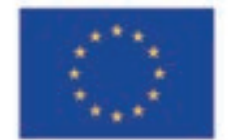

This project has received funding from the European Union's Horizon 2020 research and innovation programme under grant agreement No 871069

\section{BACKGROUND TO THE COPIM PROJECT}

COPIM (Community-led Open Publication Infrastructures for Monographs) is an international partnership of researchers, universities, librarians, open access book publishers and infrastructure providers. Funded by the Research England Development Fund, and Arcadia - a charitable fund of Lisbet Rausing and Peter Baldwin, COPIM, is building community-owned, open systems and infrastructures to enable OA book publishing to flourish.

COPIM will develop a significantly enriched not-for-profit and open source ecosystem for OA book publishing that will support and sustain a diversity of publishing initiatives and models, in the UK and internationally. To achieve its aims, the project is divided into seven work packages ranging from the technical (building open-source, community-based infrastructures that support the publication and dissemination of OA books), through to advocacy and knowledge sharing activities (establishing and consolidating partnerships between $\mathrm{HE}$ institutions and OA book publishers). 


\section{AIMS}

This report reviews existing academic and research library systems for e-content and OA book procurement. It looks into how the e-content is integrated into library catalogues and e-learning environments in chosen European countries. It examines how library communities work and deal with open access books under local OA policies. It also identifies existing funding streams, collective funding groups and consortia and looks closely at emerging new initiatives in OA book publishing, particularly those involving libraries in their publishing process.

\section{SCOPE}

While this report draws heavily on the Knowledge Exchange Landscape Study on Open Access and Monographs: Policies, Funding and Publishing in Eight European Countries (Ferwerda et al., 2017), which sheds light on how open access monographs are handled, it also aims to expand the previous work's horizons, adding new territories of exploration. Next to the often considered Western European countries, we have included those which are sometimes overlooked, trying to paint a more balanced picture of the academic library systems in Europe and understand the challenges they are facing under different regional circumstances.

We have included 14 European countries: the OPERAS core members: Croatia, France, Germany, Greece, Italy, Poland, Portugal, Slovenia, and The Netherlands, with the addition of Spain and the Nordic countries. The United Kingdom is out of the scope of this report since the UK-specific report will soon be published as an outcome of research conducted by the COPIM Work Package 2.

The presented report is informed by the recent COPIM'S report Revenue Models for Open Access Monographs (Penier et al., 2020), which helped to explain and systematise different approaches towards OA books publishing when it comes to the used revenue models.

\section{METHODOLOGY}

The report is based on a systematic literature review, desk-based research, and, perhaps even more importantly, on what we heard from the European library community in interviews and workshops. In 14 interviews, representatives of each of the analysed countries were asked general questions about country-specific library systems, OA policies and OA books publishing initiatives (see Appendix 1).

Four workshops - including two regional events for the Nordic countries (Denmark, Finland, Norway, Sweden) and for Southern Europe (Croatia, Greece, Slovenia), as well as two country-based ones for Germany and Poland - gave us a chance to ask more specific questions about roadblocks, selection criteria, and budget allocations for OA book-related projects. A survey which participants were asked to complete prior to these workshops shed more light on the level of familiarity with existing OA book publishing initiatives (see Appendix 2). A set of short reports, discussing main take-aways from each of the workshops, has been published in the form of blog posts on the COPIM website. The workshops will continue to take place in Q1 of 2021, in order to cover all the countries included in this report.

In the final stage of report preparation we asked the interviewees for their feedback on countryspecific components and COPIM colleagues for their feedback on the document. Although we were striving to paint as nuanced a picture of the landscape as possible, we acknowledge that, especially when it comes to emerging OA book publishing initiatives, there might be more out there, whose existence we are not aware of. 
The interviews have been conducted by Agata Morka, who has also organised all the workshops, and has written the present report. Rupert Gatti, as the OPERAS-P Work Package 6.2 leader, has supervised all the steps, providing general structure for the performed tasks and co-leading the workshops.

With the constantly changing landscape of academic libraries in Europe, the information gathered in this report will need to be updated. In order to keep it as accurate as possible, we decided to publish the present time-stamped version of the report (Version 1.0), which will be followed by a publication of a living document, hosted on the COPIM website. We would like to encourage the community to interact with this living document, and introduce comments and updates.

\section{DEFINITIONS}

The word "library" in this report is used to signify academic and research libraries, connected to Higher Education Institutions (HEIs). Public libraries are excluded from the scope of this report. National and special libraries might be mentioned if their role is deemed significant in handling/producing OA books.

In this report we define OA books as both scholarly monographs and edited volumes, published open access. Textbooks, having different methods of usage and acquisition criteria, are not covered by the OA book definition, therefore they are specifically referred to as textbooks.

\section{ACKNOWLEDGEMENTS}

The authors of the report would like to express their gratitude to colleagues who offered their support in guiding us through the meanders of the European library systems. The warmest thank you note to Jadranka Stojanovski, Mojca Kotar, Giannis Tsakonas, Niels Stern, Sofie Wennström, Riitta Koikkalainen, Jan Erik Frantsvåg, Bożena Bednarek-Michalska, Lluis Anglada, Elena Giglia, Eloy Rodrigues, Margo Bargheer, Jean François Lutz, and Jeroen Sondervan. We would not be able to organise and conduct regional workshops without the generous help of our colleagues: Lucy Barnes, Dan Rudmann, Joe Deville, Izabela Penier, Tom Grady, Anja Oberländer, Paul Schultze-Motel, Marta Błaszczyńska, Anna Wałek, Natalia Wysmyk and our incredible Master of Ceremonies, Tobias Steiner. We would also like to express our gratitude to colleagues who have offered their feedback on the text of the report. Among them a special mention goes to Martin Paul Eve for his attentiveness and thoughtful suggestions and to Rosalyn Sword, for her fantastic eye for detail and patience when dealing with a non-native speaker writer. 


\section{CROATIA}

\section{Key findings}

- Academic libraries in Croatia have relatively little autonomy and their collection development strategies depend on the institutional and state budget

- The open access movement has a long history in Croatia, with lots of initiatives brewing in the library community

- There is no official national OA policy; some institutions have their own OA/Open Science policies

- There are no OA book-specific funds in Croatia

- There are several library/scholar-led OA book publishing initiatives in Croatia

- Libraries rely on aggregators for OA book coverage

\subsection{GENERAL LIBRARY SYSTEM FOR E-CONTENT AND OA PUBLICATIONS}

Croatia, with its 9 public and 2 private universities, 11 public and 4 private polytechnics, 3 public and 22 private colleges, and 25 public research institutes, has approximately 95 academic and research libraries (Upisnik knjižnica Upisnik knjižnica u Republici Hrvatskoj, n.d.). Croatian higher education and research institutions are funded via institutional funding from the Ministry of Science and Education, via project funding by the National Science Foundation, and via own-income sources. Croatian academic and research libraries' services and collections are partly funded by the institutional budget, and partly directly by the state budget.

Since the Croatian academic and research community is rather small, libraries' digital collections are acquired mostly by consortial agreements at the national level and funded directly by the state budget (additionally, in the past four years, a significant proportion of funds was obtained from the European Social Fund). The license agreements with major publishers are negotiated and signed by the National Academic Consortium led by the National and University Library.

Several institutions and their libraries subscribe to (or purchase) additional e-resources for their users, with their own institutional budgets (e.g. University of Zagreb and the University of Rijeka). There are no dedicated financial lines for OA content, either at the national or institutional level.

Within this rather centralised system, there is little freedom for individual libraries when it comes to shaping their collections or investing in innovative projects, as they rely on ministerial policies and budget restrictions. The National and University Library in Zagreb, the oldest library in Croatia, acts as the central academic library for the country.

\subsection{LIBRARY COMMUNITY AND OPEN ACCESS}

It is hard to talk about an actual academic library system in Croatia, as it is more of a sum of dispersed initiatives, shaped by more active institutions, groups and individuals carrying on the OA and OS projects at the national, regional or local level. Librarians are generally in favour of open access, and, in many institutions, they are the main promoters of OA. This bottom-up approach, especially when it comes to the open access movement, has resulted in two important projects that currently act as the main systems for Croatian scientific e-content. 
The oldest OA infrastructure in Croatia is the Croatian Scientific Bibliography CROSBI, launched in 1997, which aims to collect information on all scholarly outputs of the Croatian researchers. Beside prevalent publication types like journal articles, books, and conference proceedings papers, CROSBI also stores theses, software, pre-prints and other types of research output. Metadata on more than 600,000 research outputs have been stored in CROSBI, many of them with full-text available in OA, since CROSBI serves as a national repository too.

The key component of the Croatian infrastructure for e-content is DABAR (Digital Academic Archives and Repositories). DABAR is a collaborative project uniting numerous Croatian academic institutions and researchers. It is strongly connected with both the University of Zadar and the Ruder Boskovic Institute. DABAR "provides technological solutions that facilitate maintenance of higher education and science institutions' digital assets" and its current database consists mainly of Master's and undergraduate theses (What Is DABAR? | Digital Academic Archives and Repositories, n.d.). Within DABAR 10 groups work on different aspects of the infrastructure, such as, for example, the interoperability with other repositories, the questions of preservations and user functionalities.

HRCAK, on the other hand, is the national portal for Croatian scientific journals offering open access to their content. HRCAK offers tools for print journals to switch to digital form and services for editors that help boost their journals' visibility. Currently, HRCAK does not cover books.

\subsection{OA BOOK POLICIES}

As of 2013 the Law on Science and Higher Education mandates deposition of undergraduate, graduate and doctoral theses in open access; however, Croatia does not have a national OA policy (Zakon o Znanstvenoj Djelatnosti i Visokom Obrazovanju - Zakon.Hr, n.d.). Although open access is mentioned as part of the development strategies of the Ministry of Education, released in 2014, no official plan for the OA implementation has been released (Strategy for Education, Science and Technology, 2017).

As a bottom-up initiative, the Croatian Open Access Declaration was published and signed by Croatian researchers and librarians, calling for a sustainable national infrastructure that would be able to ensure open access to Croatian scientific publications (Declaration - Open Access - Otvoreni Pristup Znanstvenim Informacijama, n.d.). In 2015 the Croatian Rectors Conference formulated a document in favour of the introduction of a national OA policy (Vrednovanje Znanstveno-Istraživačkog Rada $i$ Promicanje Otvorenog Pristupa Znanstvenim Informacijama i Istraživačkim Podacima, 2015).

There are currently two Croatian institutions with registered OA policies in the ROAR map: the Ruder Boskovic Institute (which mentions books specifically) and the University of Zagreb, Faculty of Electrical Engineering and Computing. ${ }^{1}$

\subsection{OA BOOK FUNDING}

No specific OA book funds exist in Croatia. Open access publications can be funded as part of larger research projects. The National Science Foundation (NSF) is the main funder of research in Croatia. Through its programmes, OA publications can be funded, but the overall dissemination and cooperation funds are capped at 20,000 EUR (which hardly enables financing BPCs on a national level). As a funder, the NSF does not mandate OA, and the NSF is not a signatory of Plan S.

\footnotetext{
1 Information concerning existing OA policies for all countries in this report is based on data from the Registry of Open Access Repository Mandates and Policies (ROAR), retrieved on December 3, 2020.
} 
Beside support for OA journals at Croatian academic and research institutions (only a limited number of journals is eligible for government subsidies, and an even smaller number fulfills evaluation criteria), there are no dedicated OA publishing schemes. However, the longstanding tradition of state subsidies for scientific publishing, with separate lines for journals and books, has a key role in the scholarly publishing landscape in Croatia. For journals, OA is the requirement that needs to be fulfilled in order to be eligible for subsidies, but for books it is not (both print and e-books are subsidised).

\subsection{LIBRARY/SCHOLAR-LED OA BOOK PUBLISHING}

Library or scholar-led OA book publishing initiatives have begun to spread in Croatia. However, there are only a few academic institutions with such practices in place. One example is the University of Zagreb Faculty of Humanities and Social Sciences Library, with its FF Open Press platform (FF Open Press - Izdanja Filozofskog Fakulteta u Zagrebu u Otvorenom Pristupu, n.d.), where the books published by the institution's press are made openly available. At the University of Zadar there is an open access publishing platform MorePress (MorePress, n.d.) for journals and books. There are also some very small scholar-led projects with open-access books in humanities; for example, publications of the Croatian Ethnological Society (O HED Biblioteci - Hrvatsko Etnološko Društvo, n.d.) or the e-library Stilistika, but their common problem is a lack of support for professional e-publishing.

\subsection{INTEGRATION OF OA BOOKS IN LIBRARY SYSTEMS}

Academic library discovery systems rely on EBSCO services, which include OA books, with uneven coverage. There are no special discovery systems for OA content: all publications, both open and closed, are handled by the same system.

Occasionally, some libraries will include specific open access titles in their library catalogues, but not in a systematic way.

Important contributors

Dabar (Digital Academic Archives and Repositories) https://dabar.srce.hr/en

Hrcak https://hrcak.srce.hr

CROSBI https://www.bib.irb.hr/

Croatian Academic and Research Network CARNET https://www.carnet.hr/en/

PUBMET conference http://pubmet.unizd.hr/pubmet2020/

The National and University Library in Zagreb https://www.nsk.hr/en/

Croatian Science Foundation https://hrzz.hr/en/the-foundation/organizational-structure/

FF Open Press https://openbooks.ffzg.unizg.hr

MorePress https://morepress.unizd.hr/ 


\section{DENMARK}

\section{Key findings}

- The Danish library system is in transition, with the newly-merged Royal Danish Library acting as both national library and university library

- The library community is tight-knit, with numerous projects and working groups covering $\mathrm{OA}$

- The national OA strategy is a point of reference for institutional OA policies. It excludes monographs

- There are no OA book-specific funds in Denmark

- There are few library/scholar-led OA book publishing initiatives

- Libraries rely on a cloud based system (Alma), covers OA books

\subsection{GENERAL LIBRARY SYSTEM FOR E-CONTENT AND OA PUBLICATIONS}

The Danish library system has been undergoing a profound transformation over the past three years. In 2018 a study, commissioned by the Ministries of Culture and the Ministry of Research and Education, took a closer look at the library landscape in Denmark. The report, which followed the study, has made several recommendations for the future of Danish libraries. Among other things, it recommended consolidating library services within the Royal Danish Library by, for instance, transferring the existing library consortium to it, thus shutting down DEFF (Denmark's Electronic Research Library) in June 2019 (Licensforhandlinger Skal Samles På Det Kgl. Bibliotek, n.d.).

The Royal Danish Library (RDL), which was created as a result of a merger between the State and University Library in Aarhus and The Royal Library in Copenhagen on January 1st 2017, is now the key player within the Danish library system (Danmark Får et Samlet Nationalbibliotek - Det Kgl. Bibliotek, n.d.). Its role is two-fold, as it fulfills the responsibilities of a national library, and at the same time is a university library for five Danish universities: Aarhus University, University of Copenhagen, Aalborg University, IT University and Roskilde University.

Until June 2019 DEFF acted as a Danish library consortium covering research, educational and special libraries (Beagrie, Charles, 2014). The project launched in 1998 and played a crucial role in negotiating license agreements with publishers. As of June 2019 the DEFF dissolved and its responsibilities as a national license consortium were moved to the Royal Danish Library, following the principle of efficiency. With this move a new governance structure was formed where universities in Denmark (incl. the Rectors' Conference) in collaboration with the Royal Danish Library, develop strategy and provide a total, clear strategic negotiation mandate to the largest national negotiations. Beside the eight universities in Denmark, the consortium also includes a number of university colleges and other higher education institutions, research centres, hospitals and other public agencies.

\subsection{LIBRARY COMMUNITY AND OPEN ACCESS}

Denmark, being a small country, enjoys the benefits of a close network of academic librarians. As open access in general is very much present on the universities' agenda, there have been numerous projects 
and working groups dedicated to the OA questions. However, no formalised OA-specific forum among librarians exists.

The Danish Open Access Indicator is a tool used by the Ministry of the Higher Education and Science in order to measure compliance of the Danish universities' published research output with the national open access strategy. It publishes statistics on a yearly basis, covering three main categories: realised open access (publications released as $O A$ ), unused open access rights (for publications released as non-OA in journals with embargoes of up to one year), and blocked open access (for publications released as non-OA in journals with an embargo period exceeding one year).

\subsection{OA BOOK POLICIES}

Denmark launched its national OA strategy in 2014. In its initial form it aimed at achieving open access to $80 \%$ of Danish peer-reviewed scientific articles published in 2016 by 2017 , arriving at $100 \%$ of those published in 2021 by 2022.

The strategy was revisited in 2018 and in its current state it is aiming to have $100 \%$ of all peerreviewed articles from Danish research institutions in open access by 2025, allowing for a maximum 12-month long embargo period. It covers scientific journals and conference proceedings, leaving out monographs, edited volumes and PhD theses. Another revision of the strategy is planned for 20212022 (Denmark's National Strategy for Open Access, 2018).

The strategy is being treated as a point of reference for OA-related issues by individual universities, which follow its principles in forming their OA policies.

Currently, there are eight institutions with open access policies registered in the ROAR map. Among them two mention books specifically: Copenhagen Business School, Roskilde University.

\subsection{OA BOOK FUNDING}

Public BPC-specific funds do not exist in Denmark. Until May 2020 the University of Southern Denmark's library was the only institution offering an OA-specific fund (up to 100,000 EUR per year to cover APCs and BPCs alike). The increasing interest in the fund made it impossible to sustain its existence. Since the official closure of the fund, the researchers of the University of Southern Denmark have been encouraged to upload their publications to Pure (Open Access Fund, n.d.).

\subsection{LIBRARY/SCHOLAR-LED OA BOOK PUBLISHING}

Library or scholar-led OA book publishing initiatives are rare, if not non-existent, in Denmark.

Among the rare examples is the Aarhus University - with its platform dedicated to un-edited OA material, incl. books - and Aalborg University Press, closely cooperating with the university library.

Aarhus University offers its researchers a chance to deposit their books, PhD dissertations and working papers. The service, run on the Open Monograph Press software, is provided at no fee to authors (provided they are affiliated with the university) and offers no editorial intervention. Authors are asked to submit their manuscripts as camera-ready PDF copies. Published books are available as PDFs with assigned ISBN and DOI numbers. 
Aalborg University Press offers the open access option for a wide range of publications: journals, conference proceedings, reports, edited volumes and monographs. Books are published in PDF format and hosted on the Knowledge Bade (Vindenbase: VBN) research portal.

\subsection{INTEGRATION OF OA BOOKS IN LIBRARY SYSTEMS}

The Royal Danish Library has recently introduced a new cloud-based system called Alma, which covers both closed and open sources. Before the system was introduced OA books were integrated in the library discovery systems through DOAB and OAPEN. The Danish National Research Database (central national repository/aggregator) lists more than 5,000 OA books.

\section{Important contributors}

The Royal Library https://www.kb.dk/en

Universities Denmark https://dkuni.dk/

Aalborg University Press https://aauforlag.dk/forside.aspx

The Danish Open Access Indicator https://www.oaindikator.dk

Danish National Research Database https://www.forskningsdatabasen.dk

\section{FINLAND}

\section{Key findings}

- Research libraries in Finland each have their own OA policy and act as public libraries, accessible to all citizens, regardless of affiliation or lack thereof

- The interests of university libraries are represented by the Finnish University Libraries network, while the universities of applied sciences have their own AMKIT consortium

- National OA policy excludes monographs

- The Academy of Finland offers funding for OA publications

- Helsinki University Press is a researcher-driven press offering open access publishing options for books without BPCs for authors

- Libraries rely on aggregators for OA book coverage

\subsection{GENERAL LIBRARY SYSTEM FOR E-CONTENT AND OA PUBLICATIONS}

Finland's higher education institutions can be divided in two main sectors: research universities (13) and universities of applied sciences (22) (Higher Education Institutions and Science Agencies, n.d.). Both types of institutions have their own libraries, organised in associations and consortia. Research libraries are open to the public, with minor restrictions on access to content for non-affiliates, particularly when it comes to the STM journals (In Finland LIBRARIES Basic Service for Everyone, n.d.). 
The National Library of Finland plays a pivotal role in the library landscape in Finland. Being the central information hub, it provides services to all Finish libraries. It coordinates the efforts of the FinELib, a consortium of research institutions, universities, universities of applied sciences and public libraries. FinELib facilitates access to electronic resources on a national level and represents the member institutions in negotiations with international publishers. In its strategy for 2021-2030 it mentions openness as one of its principles (Strategic Plan of the National Library of Finland 2021-2030, 2020).

The Finnish University Libraries Network (former Council for Finnish University Libraries) is an organisation representing all research universities in Finland. Although it is not a formal consortium, the body acts as a forum for the exchange of information between research libraries, and encourages collaboration and experimentation. The interests of Finnish universities of applied sciences are represented by the AMKIT consortium, which facilitates cooperation between participating institutions.

\subsection{LIBRARY COMMUNITY AND OPEN ACCESS}

The research library community in Finland seems to be tight and well-organised into associations and networks, such as The Finnish Research Library Association with 700 members or the Network of Special Libraries and Information Services.

Open access projects are handled on each institution's level with the Open Science expert panels programme acting as a project encouraging $\mathrm{OA}$ on a national level, and numerous working groups focusing on particular fields of open science, such as open education, open data, open access and open scholarship.

\subsection{OA BOOK POLICIES}

Finland has been a strong supporter of open access in Europe, with its first OA initiatives launched in 2014, and a national OA mandate for peer-reviewed articles in 2017. The Finnish Ministry of Education and Culture appointed the Federation of Finnish Learned Societies to coordinate all open science-related activities. With the help of this organisation the national policy and declaration was inaugurated in 2019. It rolls out the implementation plan for the five coming years, covering the period between 2020-2025 (Open Access to Scholarly Publications National Policy Executive Plan by the Research Community in Finland for 2020-2025, 2019). The policy's main objective is to have all newly published research articles available with open access by 2022, with no embargo periods. It covers both Finnish and international journals and should be applied in cases when authors are affiliated with a Finnish institution or funded by a Finnish funder. The policy pertains to articles and conference publications, making no mention of monographs, although their inclusion in national OA policies was much anticipated.

HEI follows the national OA guidelines while creating OA policies. There are currently 33 registered OA policies in ROARmap, among which three specifically mention book or book sections (University of Eastern Finland, University of Jyväskylä and Åbo Akademi University).

\subsection{OA BOOK FUNDING}

The Academy of Finland, following its OA policy, offers funding for OA publications as part of research grants. Funding is geared towards article publishing charges, but it can also be used towards "other types of publications", which presumably means books (Academy of Finland-Academy of Finland, n.d.). 
No OA book-specific funds are available on an institutional level.

\subsection{LIBRARY/SCHOLAR-LED OA BOOK PUBLISHING}

Back in 2016-2017, the Aleksandria library consortium was a pilot project run by the Finnish Literature Society (SKS) and Helsinki University Library (HULib), based on the Knowledge Unlatched model applied to the Finnish library environment. Participating libraries were offered a package of ten books (three forthcoming titles and seven backlist titles). The project is no longer active (Kirjastokonsortio Aleksandria - suomalainen tiedekirjallisuus avoimeksi verkkoon, n.d.).

Finnish university presses do offer open access publishing options. The relatively young Tampere University Press, founded in 2014, publishes all their books in open access, operating on a BPC model. The current BPC (as of December 2020) amounts to 2,250 EURO +VAT (Information for Authors I Tampere Universities, n.d.).

Researchers can publish their books open access with Helsinki University Press, which accepts both its affiliates and scholars from other institutions, without applying Book Processing Charges to individual authors (Helsinki University Press, n.d.).

\subsection{INTEGRATION OF OA BOOKS IN LIBRARY SYSTEMS}

For the inclusion of open access books in their catalogues and discovery systems Finnish libraries rely on aggregators. On a national level a common discovery tool based on the open source library portal called VuFind has been applied.

Important contributors

National Library of Finland https://www.kansalliskirjasto.fi/en

FinElib https://www.kansalliskirjasto.fi/en/services/licensing-services/finelib

AMKIT consortium http://www.amkit.fi/en/

Universities Finland (UNIFI) http://www.unifi.fi/in-english/

The Federation of Finnish Learned Societies (TSV) https://eusea.info/member/

federation-of-finnish-learned-societies/

The Finnish Research Library Association https://www.stks.fi/in-english/

Network of Special Libraries and Information Services https://www.kirjastot.fi/erik/

network-of-special-libraries-and-information-services

The Federation of Finnish Learned Societies https://www.tsv.fi/en

Open Science Coordination https://avointiede.fi/en/open-science-expert-panels

Aleksandria library consortium https://www.finlit.fi/en/node/2162\#.XzQohi2w2u4

finna.fi https://finna.fi/Content/about finnafi 


\section{FRANCE}

\section{Key findings}

- The academic library system is centralised around the Ministry of Education at its core

- The Couperin consortium represents French libraries on the national level

- The National Plan for Open Science, introduced in 2018, calls for open access to publicly funded publications for journal articles and books alike

- There are no OA book-specific funds in France; OA book publishing is mainly supported by grants

- No library-led OA book publishing initiatives were identified

- OpenEdition acts as an open access platform for journals and books in HSS

- Libraries rely on ABES on OA book coverage

\subsection{GENERAL LIBRARY SYSTEM FOR E-CONTENT AND OA PUBLICATIONS}

The higher education system in France has three main contributors: public universities, research centres such as the CNRS, and Grandes Écoles.

The country has historically relied on a strongly centralised academic libraries system, with the Ministry of Education at its core. Although academic and research libraries still fall under its aegis, they are also gaining more autonomy. Academic libraries are organised around institutions. In the case of public universities, each of them has its own central system with smaller faculty libraries. In order to facilitate the exchange between universities, some of them come together to form mergers of three or four institutions.

Negotiations on access to electronic e-content in France are managed by the Couperin consortium (Unified Consortium of Higher Education and Research Organisations for Access to Digital Publications), founded in 1999. It unites academic and research institutions in France and negotiates deals with publishers on their behalf. Currently Couperin has 264 members: among them are universities, research institutes and national libraries (Liste Des Membres - Membres, n.d.).

ABES (Bibliographic Agency for Higher Education) is a body responsible for the development of cataloguing standards used across libraries in France, eBooks included.

\subsection{LIBRARY COMMUNITY AND OPEN ACCESS}

ADBU (the French Association of Academic Libraries and Documentation) is a well-established organisation uniting academic libraries across the country since the 1970s, when ADBU was officially formed. The organisation takes pride in working on strategical development of the academic library, which is seen as an institution with a strongly pronounced societal role: that of innovating and providing access to knowledge (Swiatek, 2020). Open access is one of the questions that sits high on the 
discussion list in the ABDU, which supports Plan $\mathrm{S}$ and organises numerous roundtables and conferences supporting developments in open science.

Open Science Committee, an organisation that came to life in 2018 under the auspice of the Ministry of Education, is a collection of working groups dealing with a spectrum of topics that have to do with open science. Librarians constitute a large part of the working groups, alongside researchers and publishing experts. Open Science Committee defines its mission as that of leading the way and indicating directions in which open science should evolve, as well as educating people about its benefits and animating the open science community. It serves as one of the main platforms where librarians engage in discussions on open access (Ouvrir La Science - The Committee for Open Science, n.d.).

\subsection{OA BOOK POLICIES}

In 2018 France published the National Plan for Open Science, in which it committed to generalising open access for publications using public funding, structuring research data and making it available $\mathrm{OA}$, and being an active part in the $\mathrm{OA}$ international community. The Plan pertains to journals and books alike. While it outlines roadmaps for all three commitments, it does not give any specific dates by which the policy should be implemented (National Plan for Open Science, 2018). The same year saw the creation of the Jussieu Call for open science and bibliodiversity, a declaration crafted by French researchers and academic publishers. In the document they express the need for a more diverse publishing landscape, supporting the development of innovative scientific publishing models (Jussieu Call, n.d.).

Currently, there are 24 institutions with recorded OA policies in the ROAR map. Among them nine specifically mention books: Agence National de la Recherche (HSS branch), Arts et Metiers ParisTech, CIRAD (Centre de coopération internationale en recherche agronomique pour le développement), CNRS, CentraleSupélec, INRIA (National Institute for Research in Computer Sciences \& Control), Ifsttar: Institut français des sciences et technologies des transports, de l'aménagement et des réseaux, Institut Pasteur, Institut français de recherche pour l'exploitation de la mer (Ifremer).

The most important public funder in France, the French National Research Agency (ANR), supports the National Plan recommendations mandating deposits of publications coming out of funded projects into institutional or national open archives (HAL). ANR encourages publication in open access journals.

\subsection{OA BOOK FUNDING}

There are no OA book-specific funds for researchers available in France. OA publications are mainly covered by research grants. Several French libraries participate in the freemium programs available from the OpenEdition platform, therefore allocating their budgets to OA initiatives.

\subsection{LIBRARY/SCHOLAR-LED OA BOOK PUBLISHING}

Academic libraries in France do not act as publishers per se. There are several examples of libraries being involved in journal publishing (for example, at the universities of Nice, Bordeaux, Clermont and Lyon), but none involved in OA books publishing. Some libraries might be engaged in depositing theses in institutional repositories, yet they do not strictly take publishing initiatives themselves, leaving this job to a well-developed network of university presses. 
OpenEdition provides university presses with an infrastructure for hosting open access books. The platform unites open access journals, books, blogs and academic announcements. Currently there are over 10,000 OA books accessible through OpenEdition.

\subsection{INTEGRATION OF OA BOOKS IN LIBRARY SYSTEMS}

ABES (Bibliographic Agency of Higher Education) plays a crucial role in the process of cataloguing $\mathrm{OA}$ books and integrating them with library discovery systems on a national level. Some universities, in order to make sure that OA books are included in their discovery systems additionally rely on the DOAB metadata.

Important contributors

COUPERIN https://www.couperin.org

ADBU (Association française des directeurs et personnels de direction des bibliothèques universitaires et de la documentation) https://adbu.fr

Bibliographic Agency of Higher Education (ABES) https://abes.fr

Open Science Committee https://www.ouvrirlascience.fr/open-science/

Open Archives for Academic Publications HAL https://hal.archives-ouvertes.fr/?lang=en

OpenEdition https://www.openedition.org

\section{GERMANY}

\section{Key findings}

- The federal government system results in a decentralised library system across the country, with different systems used in different regions and a fair amount of independence on an institutional level

- There is a number of library consortia across the country for different regions. The interests of the German speaking countries are collectively represented by the GASCO consortium

- Open Access is a topic widely discussed among librarians, with a large number of organisations and working groups

- Although there is a strong push towards OA in Germany, no national OA policy exists. However, a number of institutions and funders have adopted OA mandates

- There is a fair number of institutional and national funding available for OA books

- There are several scholar/library-led OA book publishing initiatives

- Libraries rely on aggregators for OA book coverage 


\subsection{GENERAL LIBRARY SYSTEM FOR E-CONTENT AND OA PUBLICATIONS}

Germany's governmental system relies on a federal structure, as the country is divided into 16 states (Länder). Within this framework HEls are subject to higher education legislation, but at the same time enjoy a fair degree of autonomy, their libraries included. With nearly 400 universities (including universities, universities of applied sciences, and colleges of art and music and other subjects) Germany possesses a large number of academic and research libraries, operating under a variety of governance and administrative structures (German Rectors' Conference). Regional and institutional differences make for a complex ecosystem, where libraries are often confronted with the challenge of interoperability.

GASCO (German, Austrian and Swiss Consortia Organisation) is a library consortium for German speaking countries. GASCO consortium works across the countries' and federal states' boundaries, negotiating e-content deals with publishers.

\subsection{LIBRARY COMMUNITY AND OA BOOKS}

OA Tage ("OA days") is a conference and a meeting point for the OA community, taking place each year in a different German city. German librarians are the big part of the OA Tage community and this event serves as a platform for discussion and exchange of best practices.

The Deutsche Bibliotheksverband (DBV), the Association of German Libraries, has a special Section 4, devoted to academic libraries.

DINI (The German Initiative for Network Information) is an organisation aimed at "improving the information and communication services in higher education institutions and learned societies, and the necessary information infrastructures regionally and nationally" (DINI - Project Details, n.d.). Among the four organisations that came together to form the DINI network, academic libraries are represented by the DBV Section 4. The remaining institutions include: Consortium of German University Media Centres (AMH: Arbeitsgemeinschaft der Medienzentren der deutschen Hochschulen), Association of German University Computing Centers (ZKI: Zentren für Kommunikation und Informationsverarbeitung in Lehre und Forschung e. V.), and the research institutions and research organisations (Wissenschaftseinrichtungen und -organisationen).

ENABLE! (Bibliotheken, Verlage und Autorinnen für Open Access in den Geistes- und Sozialwissenschaften), a brand-new initiative, strives to connect libraries, publishers and researchers in an effort to facilitate Open Access in SSH. Since its formation at the beginning of 2020, the platform currently hosts over $100 \mathrm{OA}$ titles, organised in publishers' portfolios (for example, Transcript) and discipline packages, such as Open Access IT Law. The platform doubles as a networking place, with discussion boards for members. It wants to push towards and explore collaborative publishing models for OA monographs in SSH. It remains to be seen which collaborative publishing projects will be created under the aegis of ENABLE!.

\subsection{OA BOOK POLICIES}

Although Germany has been one of the foremost countries to express its commitment to the OA values with the 2003 Berlin Declaration on Open Access to Knowledge in the Sciences and Humanities (Berlin Declaration, n.d.), there is no official OA policy on a national level in the country. The German Federal Ministry of Education and Research launched its OA strategy in 2016, calling for open access to 
become a standard for all publicly funded publications, and a year later introduced a directive on the funding for Open Access (BMBF/FMER, 2016).

However, numerous academic institutions and funders have introduced their own OA policies. Four of the largest research institutes - the Helmholz Association, the Fraunhofer-Gesellschaft, the Leibniz Associaton and the Max Planck's Society and network's institutes - have policies encouraging OA publications using their funds. The major national funder in Germany, the DFG (Deutsche Forschungsgemeinschaft) has also introduced the OA mandate.

74 institutions currently show in the ROAR map with registered OA policies. Out of these 74 , twelve have OA policies that specifically include books:

- Bauhaus-Universität Weimar

- Bundesanstalt für Wasserbau (BAW/Federal Waterways Engineering and Research Institute of Germany)

- Fraunhofer-Gesellschaft

- Freiburg University

- Freie Universität Berlin

- Max Planck's Society

- Technical University Braunschweig

- Technische Universität Chemnitz

- Technische Universität Dresden

- University Passau

- Universität Konstanz

- Wuppertal Institut für Klima, Umwelt, Energie

\subsection{OA BOOK FUNDING}

Funding is available for OA books on both the national and institutional levels. The DFG offers a dedicated fund to cover Book Processing Charges and so do other funders, such as the Volkswagen Foundation and the Leibniz Consortium. A number of universities have OA book-dedicated funds, with Berlin leading the way in the number of available resources through the Humboldt University and the Technical University of Berlin OA funds. ${ }^{2}$

\subsection{LIBRARY/SCHOLAR-LED OA BOOK PUBLISHING}

Two university presses in Germany publish the largest number of OA books in the country: KIT Scientific Publishing, affiliated with the Karlruher Institute for Technology (KIT Publishing), and Goettingen University Press. The former operates on a BPC-basis. Goettingen University Press, as part of the Electronic Publishing division of the Goettingen State and University Library, offers publishing services to both its affiliated authors, and to researchers coming from outside of Goettingen University.

\footnotetext{
2 For details on institution-specific policies please see for example: DFG at https://tagteam.harvard.edu/hub feeds/3997/feed items/2793378; Berlin Universities https://tagteam.harvard.edu/hub feeds/3997/feed items/2800621
} 
Language Science Press (LSP) is a relatively new player in the academic publishing landscape (in 2012 the Open Access in Linguistics initiative was set up, which then led to the creation of LSP) in Germany. It is an academic-led initiative with a focus on linguistics, strongly embedded in the linguistic community. With supporters from prestigious universities around the world, the press publishes both open access monographs and edited volumes in SSH, and does not charge BPCs to authors. In its first three years of operation it was subsidised by a grant coming from DFG (Nordhoff, Sebastian, 2018). Currently, it operates on an institutional membership model, with participating libraries collectively funding publication, using Knowledge Unlatched as a middle-man.

\subsection{INTEGRATION OF OA BOOKS IN LIBRARY SYSTEMS}

There is no one common discovery system used across all academic libraries in Germany. The inclusion of OA books in discovery tools and library catalogues depends largely on discovery system providers/ aggregators. If OA books are not automatically included in them, then there is little chance that they will be manually added, due to the lack of human resources.

\section{Important contributors}

GASCO https://www.hbz-nrw.de/produkte/digitale-inhalte/gasco

DINI (Deutsche Initiative für NetzwerkInformation e. V.) https://www.sub.uni-goettingen.de/en/ projects-research/project-details/projekt/dini/

DFG https://www.dfg.de/dfg profil/allianz/digitale information/index.html

The National Contact Point Open Access 2020 DE: https://www.oa2020-de.org/

Open Access Network: https://open-access.network/startseite

ENABLE https://www.enable-oa.org/

The Consortium of Library Networks (AGV) https://www.dnb.de/EN/Professionell/Standardisierung/ AGV/agv.html

OA Tage https://open-access.net/community/open-access-tage

DBV (Der Deutsche Bibliotheksverband) Association of German Libraries https://www.bibliotheksverband.de/fachgruppen/sektionen/sektion-4.html

Goettingen University Press https://www.sub.uni-goettingen.de/en/publishing-open-access/ goettingen-university-press/

Transcript https://www.transcript-publishing.com/

Language Science Press https://langsci-press.org

KIT Scientific Publishing https://www.ksp.kit.edu/index.php?link=shop\&sort=all 


\section{GREECE}

\section{Key findings}

- There is no national OA strategy in Greece, yet there are bottom-up initiatives pushing towards a plan for national transition towards OA

- The academic libraries consortium, HEAL-Link, represents the interests of libraries when negotiating deals with publishers

- There are no OA book-specific funds for researchers in Greece

- Project Kallipos and Kallipos+, supported by governmental funds, is the largest publishing initiative for OA textbooks and monographs

- OA books are not included in academic library catalogues

\subsection{GENERAL LIBRARY SYSTEM FOR E-CONTENT AND OA PUBLICATIONS}

Academic libraries in Greece, affiliated with 25 Higher Education Institutions and 40 public research centres, are supervised by the Ministry of Education.

The Hellenic Academic Libraries Link (HEAL-Link) is a national academic and research library consortium, offering access to e-content to all Greek Higher Education Institutions along with certain research centres and organisations. In its current shape (as of September 2020) HEAL-Link covers nearly 27,000 journals and 139,000 books, and comprises of 43 members, uniting all HEls in Greece. The consortial budget is centralised and individual institutions depend both on the national funding coming from the Ministry and their local budgets. Certain acquisition decisions for electronic sources are made at the consortium level, while others are taken on the institutional budget level, depending on each institution's specific needs.

The HEAL-Link participates in various initiatives and schemes, such as SELL, the Southern Eastern Libraries Link. The consortium's General Assembly meets on a biannual basis and approves resource allocation for e-content on a national level. The e-content budget is proposed by the Permanent Committee for Electronic Resources, which first asks for the approval of the Board of Directors before submitting its proposal to the G.A. Among the tasks of this Committee is to negotiate renewals and/or subscription to electronic content with scientific publishers, to promote and support open access, to participate in and represent the consortium actively in actions, initiatives and schemes, and to advise the consortium on matters of scholarly communication. HEAL-Link actively supports open access initiatives, amongst other things by funding the Open Library of Humanities.

\subsection{LIBRARY COMMUNITY AND OPEN ACCESS}

The Permanent Committee of Electronic Resources plays an active role in advocating OA in the Greek academic community. It advises the HEAL-Link consortium on the matters of scholarly communication, preparing guidelines and training materials. The most recent development is the launch and operation 
of the Scholarly Communication Unit under HEAL-Link, which aims to promote OA, to support and guide the community regarding the routes of implementing $O A$, to inform about the available options provided by HEAL-Link, to publish in OA mode and to monitor the OA publications.

\subsection{OA BOOK POLICIES}

While Greece has not adopted any national OA strategy, it still has active OA advocates, notably in the librarian environment, who push for developments in this area. The Hellenic Academic Libraries Link (HEAL-Link) published a document called The Declaration on Open Science in Greece. It recognizes the importance of free access to knowledge and calls for a "smooth transition" of subscription-based academic journals to OA. The Declaration focuses solely on journals and does not mention books (Hellenic Academic Libraries Link, n.d.).

In 2018 SELL released a statement supporting the transition to open access, yet also solely focusing on journals. At the end of 2019, a bottom-up initiative Open Science Task Force, consisting of representatives of HEls and OA nodes in Greece, prepared a proposal for a National Open Science Plan.

Individual institutions are slowly adopting OA policies in Greece. Currently, there are five institutions with registered OA policies in the ROAR map. Among them, three mention books specifically: the International Hellenic University, the Technical University of Crete and the University of Patras.

\subsection{OA BOOK FUNDING}

No specific OA book funds exist in Greece. Open access monographs, book chapters and/or proceedings can be funded as part of larger research projects - as the output of research projects.

\subsection{LIBRARY/SCHOLAR-LED OA BOOK PUBLISHING}

While some Greek academic libraries run OA publishing programmes, they are mainly focused on journals, a good example being Prothiki at the Aristotle University of Thessaloniki. Library-led publishing initiatives for monographs have not, however, gained much popularity.

It is on a national level that the innovation in OA book publishing is taking place in Greece. The Kallipos project, launched in 2016 and funded jointly by the Ministry of Education and the European Social Fund, is an initiative aimed at publishing textbooks in Greek in open access. The project is led by the HEAL-Link, together with the National Research Network and the National Technical University of Athens. In 2019, a new edition of the project was launched. The Kallipos+ will include, alongside textbooks, OA monographs (Project Kallipos - Open Educational Resources, n.d.).

\subsection{INTEGRATION OF OA BOOKS IN LIBRARY SYSTEMS}

OA books are generally not included in library catalogues. There is a certain scepticism about bringing them into the existing discoverability systems, especially those records that are incomplete and missing permanent identifiers. OA textbooks by Kallipos are integrated with the library catalogues.

\section{Important contributors}

Hellenic Academic Libraries Link (HEAL-Link) https://www.heal-link.gr/en/home-2/

SELL https://www.heal-link.gr/SELL/about/ 
Kallipos (Helenic Academic Ebooks) https://www.kallipos.gr/en/

Scholarly Communication Unit (under the aegis of HEAL-Link) scholarly.heal-link.gr

\section{ITALY}

\section{Key findings}

- Academic and research libraries system in Italy is centralised, with a fair degree of autonomy on an institutional level

- A working group CARE within the Conference of Italian University Rectors represents academic libraries in deal negotiations for e-content

- There is no central national OA policy in Italy

- There are no OA book-specific funds in Italy; OA book publishing is mainly supported by grants

- No library-led OA book publishing initiatives were identified

- OA books are not included in the National Catalogue

\subsection{GENERAL LIBRARY SYSTEM FOR E-CONTENT AND OA PUBLICATIONS}

Academic and research libraries in Italy - associated with public and private universities, polytechnics and research centres - depend on the Ministry of University and Research (Ministero dell' Università e della Ricerca, MUR). Each academic library has its own acquisition budget and makes its own acquisition decisions, based on the advice received from the Consiglio di Biblioteca:a governance body, at individual library level, consisting of researchers.

CRUI (Conference of Italian University Rectors), funded in 1963, acts as a body addressing crucial questions in the Italian academic world, preparing frameworks and proposals for its development. As part of its mission it aims to "experiment[ing] with new models and methodologies that can be adopted by universities" (Mission - CRUI - Conferenza dei Rettori delle Università italiane, n.d.). While there are no academic libraries consortia in Italy, within CRUI, a working group called CARE (Coordinamento per l'Accesso alle Risorse Elettroniche aka. Coordination for Access to Electronic Resources) handles acquisition of e-content. Acting as a consortium, it represents Italian universities when negotiating deals for e-content with publishers.

\subsection{LIBRARY COMMUNITY AND OPEN ACCESS}

The Italian Libraries Association (AIB), funded in the 1930s, is the oldest organisation of its kind in Italy. It unites librarians and information science students, and is open to non-Italian members. The organisation is divided into working groups and committees, one of which is devoted to academic and research libraries. Within the association, a special focus group, the GOAPD (Gruppo di studio Open Access e Pubblico Dominio), deals with open access, with a mission of sharing best practices and promoting the idea of open science. 
AISA (Associazione italiana per la promozione della scienza aperta), a non-profit organisation whose mission is to advance open science, plays a significant role in the national dialogue on the matter since its creation in 2015. Its advisory board has a strong representation of librarians.

The library community also discusses open science related issues in more informal groups, such as the Italian Open Science Support Group (IOSSG), funded in 2016. Currently 10 universities participate in the working group alongside the Open AIRE project. IOSSG aims at facilitating transition towards open access, focusing on the issues of services and infrastructures and tackling those of governance, data management and research-related processes. The organisation creates templates of open sciencerelated documents that can be adopted on an institutional level and plays an active part in the open science dialogue on a national level.

\subsection{OA BOOK POLICIES}

Currently, there is no national open access policy in Italy. According to a law introduced in 2013, based on the Decree Urgent provisions for the protection, enhancement and promotion of cultural assets, activities and tourism, all research funded at least $50 \%$ by public funds is required to be published as open access (Legge n. 112/2013, n.d.). In 2018 the Ministry of Research and Universities formed a group of experts to formulate a National Roadmap for Open Science. This roadmap, presented in May 2019 , is still to be implemented.

Currently, there are 28 institutions in the ROAR map with registered OA policy in Italy. Among them, 17 specifically mention OA books:

- Fondazione Cariplo

- Istituto Superiore di Sanità

- Universita degli studi di Trieste

- Universita di Pisa

- University Federico II Napoli

- University of Bergamo

- University of Bologna

- University of Brescia

- University of Padova

- University of Trento

- University of Udine

- University of Catania

- Università degli Studi di Ferrara

- Università degli Studi di Foggia

- Università degli Studi di Milano

- Università degli studi di Cassino e del Lazio Meridionale

- University of Turin 


\subsection{OA BOOK FUNDING}

Funding for open access books in Italy does not exist: there are no OA book-specific funds on a national or institutional level. OA publications are often financed through research grants.

\subsection{LIBRARY/SCHOLAR-LED OA BOOK PUBLISHING}

There are no library/scholar-led OA book publishing initiatives in Italy. The academic publishing landscape is dominated by university presses, among which three are fully open access: Firenze University Press, Trieste University Press and Naples University Press. They operate on a BPC model. Firenze University Press charges 2,500 EUR for a 230 page monograph or edited volume, including 100 free print copies for the author (VII. Revenue sources and publication charge policy, n.d.).

The University of Torino runs its own open access publishing platforms for journals (SIRIO) and for books. The latter offers OA publishing for books, released in PDF format only.

\subsection{INTEGRATION OF OA BOOKS IN LIBRARY SYSTEMS}

Open access content is not included in traditional library catalogues across Italy; they do not belong in the National Catalogue. On an institutional level, each university operates on its own discovery system which may or may not include OA books. Among popular discovery tools in use is PRIMA.

\section{IMPORTANT CONTRIBUTORS}

CRUI (THE CONFERENCE OF ITALIAN UNIVERSITY RECTORS) https://www.crui.it/crui-english.html Italian Open Science Support Group/IOSSG https://sites.google.com/view/iossg/home AISA (Associazione italiana per la promozione della scienza aperta) The Italian Libraries Association (AIB) https://www.aib.it/aib/cen/presaib-e.htm GOAPD (Gruppo di studio Open Access e Pubblico Dominio) https://www.aib.it/struttura/ commissioni-e-gruppi/gruppo-studio-open-access-pubblico-dominio/

SIRIO@ UniTO https://www.ojs.unito.it

\section{NORWAY}

\section{Key findings}

- Research libraries in Norway are part of independent units - universities and research centres - with their own institutional policies

- The UNIT consortium represents research libraries in licence negotiations with publishers

- National OA guidelines exclude monographs

- Sources of funding for OA books are available on an institutional level

- No library/scholar-led OA book publishing initiatives (small output of monographs) were identified

- Libraries rely on common catalogue offered by UNIT (Alma) for OA book coverage 


\subsection{GENERAL LIBRARY SYSTEM FOR E-CONTENT AND OA PUBLICATIONS}

The landscape of research libraries in Norway is heterogeneous, with individual, institution-based libraries which differ greatly in size, available funding and resources. Collectively, they are represented by the library committee of the Universities of Norway (UHR). UHR is a cooperative body in the higher education landscape in Norway, which plays a vital role in giving advice on open access-related questions to the entire sector. It stands for 33 universities and university colleges and is divided into strategic units. One of them is dedicated to research libraries.

Their interests are also represented by the the newly-formed organisation called UNIT.

UNIT (The Norwegian Directorate of Information and Communications Technology and Joint Services in Higher Education and Research) is an agency of the Ministry of Education and Research, established in 2018. As part of its mission, UNIT coordinates work on open access on a national level and is in charge of negotiations of licence agreement for e-content with publishers. It represented Norway in talks with Taylor and Francis, Springer, Elsevier and Wiley. Library participation in the UNIT consortium is voluntary. Currently the organisation gathers public, county and research libraries, as well as hospitals and institutions, under the aegis of the government. Members of the consortium operate on the basis of the "open consortia" idea, meaning that they can choose in which licence agreements they will participate.

Norwegian national strategy for libraries for the upcoming three years (2020-2023) focuses on three main areas: dissemination, cooperation and development, and infrastructure. It calls for a greater interoperability and cooperation between the public and research libraries, with UNIT and the higher education institutions working together on common standards, metadata and ensuring access to digital sources. The strategy hints at the fact that special funding will be allocated towards these goals (National Strategy on Access to and Sharing of Research Data, n.d.).

\subsection{LIBRARY COMMUNITY AND OPEN ACCESS}

Norway is one of the European front runners when it comes to the open access movement and the library community has played its part in the adoption of OA principles. In 2005, as a product of cooperation between four Norwegian universities, an organisation called NORA was founded. Its goal was to be the forum of exchange for the common repositories standard and it was intended to serve as a source of information about the OA for the academic community in Norway (Frantsvåg, 2008). It ceased to exist in 2011 when Cristin, a national organisation, formed under the aegis of the Ministry of Education with a mission of dealing with all OA issues on a national level. Currently Cristin is part of UNIT.

Despite high OA awareness among Norwegian librarians, there are no OA specific working groups within the library community in Norway. The issue of open access has been so engrained in the academic system, though, that it is hard to imagine any discussion about the future of scholarly communications in Norway that would exclude the notion of open access to science. openaccess.no is a website gathering news on open access-related questions on a national level. It is steered by UNIT.

\subsection{OA BOOK POLICIES}

Norway has been a strong supporter of open access in the European landscape. In 2017 the country introduced its national goals and guidelines, with an ultimate goal of having all publicly funded 
research articles OA by 2024 (National Goals and guidelines for Open Access to Research Articles, 2017). OA monographs, however, are not mentioned in the document. Despite several rumours concerning their soon-to-be introduction to the national OA goals, books still remain uncovered.

Alongside OA guidelines on a national level, each HEI has its own policy that their libraries follow. Eight institutional OA policies have been recorded in ROAR for Norway, with three institutions specifically listing books as a type of content covered by the OA policy (University of Stavanger, University of Bergen and University College of Southeast Norway).

\subsection{OA BOOK FUNDING}

Norway benefits from the strong support of the Research Council of Norway, which allocates substantial funds to cover the costs of OA publications. The RCN runs a program called STIM-OA, rolled out on a yearly basis, to which Norwegian research institutions can apply. Available funding support accounts for $50 \%$ of the OA publication costs, but so far can be used for APCs only. The need for BPCs to be included in the funding scheme has been communicated by the academic community, but no changes have been introduced as of the end of 2020. STIM-OA, introduced in 2015, has entered its second phase now, planned till 2022 (Open Access to Publications, n.d.).

In addition to this central funding, there are options for OA book funding available on an institutional level. Nineteen Norwegian institutions currently have their own institutional OA funds (Publiseringsfond ved norske UH-institusjonar - frontpage, n.d.). While the majority of them is geared towards journal publication fees, nine institutions mention that their funds can also be used to cover book processing charges.

\subsection{LIBRARY/SCHOLAR-LED OA BOOK PUBLISHING}

No library/scholar-led OA book publishing initiatives were identified.

\subsection{INTEGRATION OF OA BOOKS IN LIBRARY SYSTEMS}

All HEls in Norway use a common catalogue system offered through UNIT: Alma from ExLibris and Oria as a search system. Libraries depend on Alma for the inclusion of OA books that should be included in it automatically. Single titles coming from smaller publishers and not included in Alma might be added to the catalogue manually by librarians.

NORA - Norwegian open research archives - is the central portal to all national OA output, including more than 6,000 OA books.

\section{IMPORTANT CONTRIBUTORS}

UNIT https://www.unit.no/en/about-unit-0

The Research Council of Norway https://www.forskningsradet.no/en/

Universities Norway (UHR) https://www.uhr.no/en/about-uhr/

open.access.no https://www.openaccess.no

NORA https://nora.openaccess.no/ 


\section{POLAND}

\section{Key findings}

- Academic libraries system in Poland is centralised, with relative autonomy on an institutional level

- The open access movement in Poland is a bottom-up initiative, with libraries playing an important role in pushing for $\mathrm{OA}$

- A national OA policy was introduced in 2015 and covers books. It has been slowly adopted by institutions since then

- There are no OA book-specific funds for researchers in Poland

- There are no library/scholar-led OA book publishing initiatives

- Libraries rely on aggregators for OA book coverage

\subsection{GENERAL LIBRARY SYSTEM FOR E-CONTENT AND OA PUBLICATIONS}

Academic libraries in Poland fall under the aegis of the Ministry of Science and Higher Education; however, they are relatively autonomous bodies that depend on the local decisions of each university's governance. In order to facilitate their work, academic libraries in Poland tend to organise themselves in consortia. Numerous such consortia exist, such as, the Federation of Digital Libraries (Federacja Bibliotek (yfrowych), which gathers digital content from Polish libraries, museums and archives.

The International Centre of Mathematical and Computational Modelling (ICM) at the University of Warsaw is the crucial player when it comes to e-content. It acts as a national consortium for negotiating license agreements with large publishers. It is responsible for both the national licenses (covering about $550 \mathrm{HEIs}$ ) and the consortia licenses (covering 20-50 institutions). ICM hosts the Virtual Library of Science (Wirtualna Biblioteka Nauki) - a database of electronic sources (journals, books, databases) from publishers such as Springer Nature, Wiley, Elsevier and others - and grants access to academic institutions in Poland. For Polish academic publications ICM curates the Library of Science for journal articles (as of 2019 it covered 1000 journals and 300K articles) and the platform Open Up a Book (Otwórz książkę): a repository of Polish academic books, which are no longer available in print (as of 2020 it covered 408 authors and 544 books).

Part of the ICM, the Open Science Platform (Platforma Otwartej Nauki=PON) acts as a centre of knowledge and best practice sharing when it comes to the implementation of open access models in academic institutions. PON publishes extensively about the status of open data and open science in Poland.

\subsection{LIBRARY COMMUNITY AND OPEN ACCESS}

The open access movement is very much a bottom-up initiative in Poland, in which librarians seem to be the pioneers, leading the way. The late nineties saw the emergence of the first Polish OA journals, among them the Biuletyn EBIB (1999), which was geared towards librarians. In the following years Polish librarians, together with Polish researchers, were also early to sign ground-breaking OA declarations (the Budapest and Berlin OA and the OECD Declaration to Access to Research Data from Public 
Funding), long before the question of OA entered official debates in the Ministry of Science and Higher Education.

The Coalition for Open Education (Koalicja Otwartej Edukacji = KOED), an NGO founded in 2008, plays an important role in advancing open access in Poland. Its mission is supported by the Association of Polish Librarians and the EBIB Association. KOED's platform Uwolnij naukę ("set the science free") gathers the most up-to-date OA related news and offers advice on OA for researchers, publishers and librarians. Together with EBIB, KOED organises some of the most important OA conferences in Poland. KOED has also released a number of reports on the status of OA in the Polish context and organises Open Access Week events in Poland on a yearly basis.

\subsection{OA BOOK POLICIES}

Open access has been on the radar of the Polish Ministry of Science and Higher Education since about 2010, when the first report on OA in the Polish context was commissioned. The document, published in 2011, pointed out main roadblocks and developed a plan of implementation of OA policy on a national scale.

In 2015 the Ministry of Science and Higher Education released an official OA policy document outlining strategies for the development of open access in Poland (Kierunki Rozwoju Otwartego Dostępu Do Publikacji i Wyników Badań Naukowych w Polsce, n.d.). The document does not mandate open access, yet discusses general recommendations for actions to be taken to publish all publicly funded research in OA. It recommends green OA, with deposits in institutional repositories as soon as possible after publication (but not later than six months for STM and 12 months for HSS). While the document mainly pertains to journal articles, it also mentions books, stating that they too should be made available in OA, yet with more flexible embargo periods. According to these recommendations, all HEls are encouraged to adopt their own OA policies and appoint OA officers on institutional level.

There are currently seven Polish institutions with OA policies registered in the ROAR map. Among them, five mention books specifically: Cracow University of Economics, Institute of Nuclear Physics, ICM University of Warsaw, Medical University of Lodz, and the Nofer Institute of Occupational Medicine in Lodz. In 2020 the National Centre of Science (Narodowe Centrum Nauki) also introduced an OA policy for all publications funded by this institution (Wprowadzenie Polityki Otwartego Dostępu Do Publikacji Powstałych w Projektach Badawczych / Narodowe Centrum Nauki, n.d.).

\subsection{OA BOOK FUNDING}

Funding for open access in Poland is hard to come by. There are no OA book-specific funds on a national or institutional level.

\subsection{LIBRARY/SCHOLAR-LED OA BOOK PUBLISHING}

There are no library/scholar-led OA book initiatives in Poland. Most academic books are published either with international legacy publishers or local university presses.

The University of Torun Press (UMK), together with the University of Torun Library, has been one of the pioneers when it comes to creating open access publishing platforms. In 2013 UMK launched a platform for OA journals (Academic Platform of Journals/ Akademicka Platforma Czasopism). As part of its recent development, the UMK now also publishes OA monographs. 


\subsection{INTEGRATION OF OA BOOKS IN LIBRARY SYSTEMS}

$\mathrm{OA}$ books are integrated with general library discovery systems that, in most academic libraries, rely on EBSCO services. In order to make sure that the users have access to OA books (as they are sometimes not fully covered by EBSCO), libraries sometimes also add links to DOAB and OAPEN to facilitate browsing through a global OA book portfolio. In addition to that, CEON (aggregator for Polish research output) lists $\sim 4.400$ OA books available in repositories.

Important contributors

Koalicja Otwartej Edukacji (Coalition for Open Education) http://koed.org.pl/?lang=en

Uwolnij naukę https://uwolnijnauke.pl

International Centre of Mathematical and Computational Modelling (ICM UW) https://icm.edu.pl/ en/

ICM UW Platforma Otwartej Nauki i projekt Otworz ksiazke http://pon.edu.pl

ICM UW Wirtualna Biblioteka Nauki (Virtual Library of Science) https://wbn.icm.edu.pl

EBIB Association http://www.ebib.pl/?page id=3611 and portal EBIB http://www.ebib.pl/

Wirtualna Biblioteka Nauki (Virtual Library of Science ) https://wbn.icm.edu.pl/o-wbn/

https://fbc.pionier.net.pl/

University of Torun Press (UMK) https://wydawnictwo.umk.pl/pages/30/o-nas

\section{PORTUGAL}

\section{Key findings}

- Access to e-content for HEls is managed by the B-on consortium

- The OA-oriented library community operates within the RCAAP network

- There is no national OA policy, although a set of recommendations for open science was developed on a national level

- There are no OA book-specific funds in Portugal; OA book publishing is mainly supported by grants

- No library-led OA book publishing initiatives were identified. Some university presses offer OA option for books

- Libraries rely on aggregators for OA book coverage

\subsection{GENERAL LIBRARY SYSTEM FOR E-CONTENT AND OA PUBLICATIONS}

The higher education system in Portugal is divided between universities and polytechnic schools (both public and private). Academic libraries connected to these institutions are of diverse natures: 
there are the ancient universities (University of Coimbra library, which dates back to the XIII century), relatively young institutions (a large number of new public universities was established in 1970s), and newborns (such as the University of Lisboa, established as a result of a merger of the University of Lisbon and Technical University of Lisbon in 2003).

It wasn't until the 1990s that Portuguese academic libraries underwent a modernisation process and the past 20 years were marked by the creation of many new library buildings across the country. Despite this revamping process, Portuguese libraries still struggle with low budgets and the problem of understaffing.

B-on (Biblioteca do Conhecimento Online, Online Knowledge Library), launched in 2004, provides access to e-content to Higher Education Institutions in Portugal and negotiates deals with publishers on behalf of them. In its mission statement it cites free access to knowledge and promotion of Portuguese research publications. Currently, B-on offers access to over 16,000 publications and focuses mainly on journals. B-on was developed as a national consortium under the aegis of the Portuguese government; libraries and research centres were invited to join and currently most of Portuguese HEls are part of it.

\subsection{LIBRARY COMMUNITY AND OPEN ACCESS}

RCAAP, the Scientific Repositories of Open Access of Portugal (Repositórios Científicos de Acesso Aberto de Portugal) is a platform aggregating content of repositories across the Portuguese Universities. Across the country, it unites librarians interested in open science. Originally funded by the Foundation for Science and Technology (Fundação para a Ciência e a Tecnologia), with the support of the University of Minho, RCAAP's mission goes beyond creation of repositories, and the network of people engaged in the project can be seen as one of the important forums for information exchange for the library community.

BAD (Associação Portuguesa de Bibliotecários, Arquivistas, Profissionais da Informação e Documentação) has been uniting representatives of the library community since 1973. Several working groups have been established within the organisation, dealing with different types of libraries and their specificities, including one for HEl's libraries.

\subsection{OА BOOK POLICIES}

There is no national open science policy in Portugal. However, since 2016 the Ministry of Science, Technology and Higher Education has undertaken several steps to advance the development of open science practices in Portugal, starting with proclaiming it as a national priority. Two reports, one on the state of open science and the other with recommendations for further steps were produced in 2016 (Finanças, Cultura e Ciência, Tecnologia e Ensino Superior, 2016; Diário Da República, 2016). Among recommendations one can find transitioning to open access, and the development of necessary infrastructures to support it (Segundo Relatório Da Comissão Executive Do Grupo de Trabalho Para A Política Nacional de Ciência Aberta, 2016). The set of recommendations has not been officially adopted on a national scale yet.

The largest national funder, Fundação para a Ciência e a Tecnologia (FCT), has introduced the open access mandate, as have many HEls in Portugal. Currently, there are 27 institutions with a registered OA policy in the ROAR database. Among them, 13 mention OA books specifically: 
- Escola Superior de Educação de Paula Frassinetti

- Fundação D. Anna de Sommer Champalimaud e Dr. Carlos Montez Champalimaud Fundação para a Ciência e a Tecnologia

- ISCTE-IUL - Lisbon University Institute

- Instituto Politécnico de Bragança

- Instituto Politécnico de Portalegre

- Universidade Aberta

- Universidade Católica Portuguesa

- Universidade da Beira Interior

- Universidade da Madeira/ Biblioteca

- Universidade de Lisboa (University of Lisbon)

- Universidade do Minho

- University of Coimbra

\subsection{OA BOOK FUNDING}

Funding for open access in Portugal does not exist per se: there are no OA book-specific funds on a national or institutional level. OA publications are often financed through research grants.

\subsection{LIBRARY/SCHOLAR-LED OA BOOK PUBLISHING}

There are no pure library-led OA book publishing initiatives in Portugal. Most universities engage in publishing activities, offering both closed and open access publications. The largest and oldest publisher - University of Coimbra Press - does offer options to publish open access books, with almost 600 titles currently listed in DOAB.

Minho University, one of the OA-oriented universities, was closely involved in the development of the RCAAP project, and created its own university press in 2019, with its first OA titles being published that year. U Minho Editora publishes journals and books alike and is built on the open source software (OJS and OMP). Books are released in PDF format only. U Minho Editora does not charge BPCs to authors; they sustain their publishing activities with their own institutional budget combined with funding from public and private entities, and print sales.

\subsection{INTEGRATION OF OA BOOKS IN LIBRARY SYSTEMS}

Open access books are integrated in most library systems through discovery tools, offered by such providers as EBSCO and MetaLib. Most libraries also catalogue OA books in their local catalogues. Next to that, RCAAP, the national repository aggregator, lists more than 15,000 OA books from 10 different Portuguese repositories.

\section{Important contributors}

b-on https://www.b-on.pt/en/

RCAAP (Repositórios Científicos de Acesso Aberto de Portugal) https://www.rcaap.pt 
Fundação para a Ciência e a Tecnologia https://www.fct.pt/fct/

Higher Education Libraries Work Group of BAD (Associação Portuguesa de Bibliotecários, Arquivistas, Profissionais da Informação e Documentação) http://www.apbad.pt

UMinho Editora https://ebooks.uminho.pt/index.php/uminho/catalog/book/16

\section{SLOVENIA}

\section{Key findings}

- The academic library system is dispersed with a large number of faculty libraries, each with their own acquisition strategy

- The national OA policy is kept in line with the Horizon 2020 directives and encourages, yet does not mandate, open access for monographs

- There are no OA book-specific funds in Slovenia

- The Faculty of Arts at the University of Ljubljana has its own, scholar-led OA book publishing initiative

- Libraries rely on aggregators for OA book coverage

\subsection{GENERAL LIBRARY SYSTEM FOR E-CONTENT AND OA PUBLICATIONS}

Slovenia has three major public universities (University of Ljubljana, University of Maribor, and University of Primorska), and numerous research institutions, each with its own local faculty libraries, adding up to as many as 37 per institution (in the case of the University of Ljubljana). While the National and University Library (NUK) acts as the central academic library of the country, the system is far from being centralised: each of the smaller libraries has its own acquisition budget and strategy. NUK is responsible for the e-content, as it hosts the Digital Library of Slovenia (a national portal providing access to digitised Slovenian scholarly publications) and coordinates consortia deal negotiations on the national level.

Slovenian libraries are organised into several consortia, according to the subject of the content they acquire.

COSEC falls under the NUK's aegis and is in charge of acquisitions of the international digital sources in the field of HSS, while another consortium led by the Central Technological Library covers STM e-resources.

The Open Science Slovenia portal unites institutional repositories and provides information on open science developments in the country.

\subsection{LIBRARY COMMUNITY AND OPEN ACCESS}

Odprta knjižnica (The Open Library Competence Centre) is a joint initiative of three Slovenian university libraries: the University of Primorska, of Maribor and of Ljubljana, under the auspices of the Ministry of Education, Science and Sport. The initiative is an important player in the open access 
community in Slovenia, engaging in both national and international dialogue about matters concerning open science, such as OA mandates, policies, licensing, etc. The centre provides researchers and anyone interested in the principles of open science with free information and guidance on such topics as open publications, research data management, citizen science and open education.

\subsection{OА BOOK POLICIES}

Slovenia has a national open access strategy, introduced in September 2015, aligned with the Horizon 2020 priorities and covering the period of 2015-2020 (Research Infrastructure Roadmap 2011-2020 2016, 2016). It mandates open access for academic articles published as an outcome of publicly funded projects and encourages it for monographs. In 2017 an action plan was released, outlining the implementation process of transformation to OA (Akcijski Načrt Izvedbe Nacionalne Strategije Odprtega Dostopa Do Znastvenih Objav In Raziskovalnih Podatkov v Sloveniji 2015-2020, 2017).

Currently, there are eight institutions with registered OA policies in the ROAR map. Among them, four mention books specifically: the Central Technological Library at the University of Ljubljana, the University of Maribor, the University of Nova Gorica and the University of Pomorska.

\subsection{OА ВООК FUNDING}

No specific OA book funds exist in Slovenia. Open access publications can be funded as part of larger research projects. The Slovenian Research Agency (SRA) plays an important role, both as provider of research and as a provider of publishing grants for academic presses in Slovenia.

\subsection{LIBRARY/SCHOLAR-LED OA BOOK PUBLISHING}

\section{E-books - Ljubljana University Press, Faculty of Arts}

The Faculty of Arts, associated with the University of Ljubljana, is among the largest academic publishing houses in Central/Eastern Europe. Their portfolio also includes open access journals, closed access textbooks and OA monographs and edited volumes. Run by scholars, the press publishes around 70 OA books per year in PDF format. While it serves mainly as a publishing unit for researchers affiliated with the faculty, authors from other departments and institutions can also submit their proposals there. No Book Processing Charges are applied to authors.

The press is largely subsidised by the Slovenian Research Agency (SRA), whose funding covers up to $60-70 \%$ of the OA publishing costs. The press depends on successful applications for the SRA funds, which are allocated on a yearly basis. The remaining $40-30 \%$ of costs is covered jointly through print sales and funding coming from the Faculty of Arts itself.

The press introduced their OA model in 2015, following recommendations of the national OA strategy at the time, encouraging open access for publicly funded academic books with the goal of having $100 \%$ of them OA by 2020 . 


\subsection{INTEGRATION OF OA BOOKS IN LIBRARY SYSTEMS}

Academic libraries' discovery systems rely on COBISS services, which include OA books. There are no special discovery systems for OA content; all publications, both open and closed are handled by the same system.

\section{Important contributors}

The National and University Library (NUK) https://www.nuk.uni-lj.si/eng/\#

The Digital Library of Slovenia http://dlib.si

Slovenia Research Agency https://www.arrs.si/en/

Odprta knjižnica http://odprta-knjiznica.si

COSEC https://cosec.nuk.uni-lj.si/en

Central Technological Library at the University of Ljubljana http://www.ctk.uni-lj.si/konzorciji-ctk/

E-books - Ljubljana University Press, Faculty of Arts https://e-knjige.ff.uni-lj.si/znanstvena-zalozba/ index

Open Science Slovenia http://www.openscience.si/default.aspx

\section{SPAIN}

\section{Key findings}

- The academic system is decentralised, relying on 17 regions with numerous regional library consortia

- REBIUN is a crucial network for Spanish academic libraries

- The National Open Access Policy, introduced in 2011, encourages, but does not require, deposition of publications in open access repositories. The law focuses on journals and does not mention books

- There are no OA book-specific funds in Spain

- No scholar/library-led OA book publishing initiatives were identified

- Libraries rely on aggregators for OA book coverage

\subsection{GENERAL LIBRARY SYSTEM FOR E-CONTENT AND OA PUBLICATIONS}

The higher education system in Spain relies on universities: there are more than 80 of them across the country, with the majority being publicly funded (Registro de Universidades, Centros y Títulos, 2020). Due to the country's decentralisation into autonomous regions, universities are being self-governed in each of the 17 regions. Academic libraries belonging to them have their own budgets at their disposal, comprised of regional and national-level funds (Echeverría \& Jiménez, 2011). 
In the 1980s academic libraries started uniting into consortia, the first one being the CBUC (Consorcio de Bibliotecas Universitarias de Cataluña), serving the interests of libraries in the community of Cataluña. There are several regional academic libraries consortia: CBUA (for the community of Andalusia), MADRONO (for the region of Madrid), BUCLE (for Castilla-Leon), and BUGALICIA (for Galicia). These consortia are in charge of negotiating deals with large commercial publishers for access to e-content.

The Association of Universities' Rectors (CRUE), comprising Spanish universities representatives, acts as an interlocutor between regional universities and the central government, advising on the most important questions concerning Spanish HEI development. CRUE is one of the crucial contributors on the higher education scene in Spain and is involved in open access discussions on a national level, including negotiations of deals on e-content with large commercial publishers.

\subsection{LIBRARY COMMUNITY AND OPEN ACCESS}

REBIUN (Spanish Network of University Libraries) is an organisation uniting representatives of academic libraries nation-wide and acts as a main discussion forum for librarians. It comprises several working groups, one of them dealing with questions of open access, with a special focus on repositories. The group is currently composed of 36 members representing 27 Spanish academic institutions (Repositorios | Red de Biblioteca Universitarias Españolas, n.d.).

The Spanish Foundation for Science and Technology (FECYT), operating under the auspices of the Ministry of Science and Innovation, is the crucial player on the open access scene in Spain. It oversees the implementation of open access-related developments in Spain, deals with questions of open science infrastructure, interoperability and standardisation, and provides information and guidance on open-access-related questions to institutions and researchers.

FECYT, together with REBIUN, runs the RECOLECTA (Open Science Harvester) project, which aims to gather institutional OA repositories in one national platform for open scientific content. RECOLECTA is a significant forum for the library community in Spain, offering advice on open-science-related questions to local repositories' managers.

\section{3. ОА ВООК POLICIES}

In 2011 the Spanish government released Ley 14/2011 which encourages the ,deposition of publicly funded publications in open access repositories (Ley 14/2011, de 1 de Junio, de La Ciencia, La Tecnología y La Innovación., 2011). The law does not require, yet does recommend, OA and focuses on journal publications, making no explicit mention of how books should be treated. The question of open access has been raised in the subsequent State Plans for Research, Development and Innovation (2013-2016 and 2017-2020), which stated the push towards open science as being one of their core objectives (Spanish National Plan For Scientific and Technical Research and Innovation, 2013; Plan Estatal de Investigación Cientifica y Técnica y de Innovación, 2017).

Currently, there are 43 institutions with open access policies registered in the ROAR map. Among them twenty mention books specifically:

- CEU Cardenal Herrera University, Repositori Obert de Coneixement de l'Ajuntament de Barcelona (BCNROC)

- Spanish General State Administration 
- Spanish National Research Council (CSIC)

- Universidad Complutense de Madrid

- Universidad Internacional de La Rioja

- Universidad Politécnica de Cartagena

- Universidad Politécnica de Madrid

- Universidad Pública de Navarra

- Universidad Rey Juan Carlos

- Universidad de Burgos

- Universidad de Extremadura

- Universidad de Granada

- Universidad de León

- Universidad de Sevilla

- Universitat Oberta de Catalunya (Open University of Catalonia, UOC)

- Universitat Politecnica de Valencia

- Universitat Politècnica de Catalunya (UPC)

- Universitat de Lleida

- Universitat de Vic

\section{4. ОА ВООК FUNDING}

Funding for open access in Spain does not exist per se: there are no OA book-specific funds on a national or institutional level. OA publications are often financed through research grants. After the economic crisis of 2009, Spanish universities have suffered severe budget cuts, which affected libraries and the available publication/acquisition funds.

\subsection{LIBRARY/SCHOLAR-LED OA BOOK PUBLISHING}

No typically scholar/library led OA book publishing initiatives were identified. Some university presses offer an option to publish scholarly books in OA (for example UPV, UPC), with the Publicacions de la Universitat Rovira i Virgili (URV) being a fully OA born publisher.

The existing university presses are rather traditional and not OA-oriented.

Revistas is a publication initiative that processes OA books, publishing them in PDF format. The press does not charge BPCs to authors. It is covered by the Spanish National Research Council (CSIC). Revistats publishes 70-90 books per year.

\subsection{INTEGRATION OF OA BOOKS IN LIBRARY SYSTEMS}

Open access books are integrated in the Spanish library catalogues and discovery tools in use.

Important contributors

Spanish Foundation for Science and Technology https://www.fecyt.es/en 
State Research Agency AEI https://www.ciencia.gob.es/portal/site/MICINN/menuitem.8d78849 a34f1cd28d0c9d910026041a0/?vgnextoid=664cfb7e04195510VgnVCM1000001d04140aRCRD\&l ang choosen=en

Spanish National Research Council (CSIC) https://www.csic.es/en/csic

Association of Universities' Rectors (CRUE) https://www.crue.org

Spanish Foundation for Science and Technology (FECYT) https://www.fecyt.es/en/info/presentation

RECOLECTA https://www.recolecta.fecyt.es

REBIUN (Spanish Network of University Libraries) https://www.rebiun.org

REVISTAS http://revistas.csic.es/index.html

Consorcio de Bibliotecas Universitarias de Galicia (BUGALICIA) http://www.bugalicia.org

Consorcio de Bibliotecas Universitarias de Andalucía (CBUA) https://www.cbua.es/

Consorcio MADRONO http://www.consorciomadrono.es/en/acerca-de/

Consorcio de Bibliotecas Universitarias de Cataluña https://www.csuc.cat/es/bibliotecas

\section{SWEDEN}

\section{Key findings}

- The National Library of Sweden is the main body investigating OA-related issues. The National Library of Sweden is responsible for coordinating OA-related issues and keeping track of costs on a national level

- The National Library also runs the Bibsam consortium, which serves as a vehicle for the shift to OA by negotiating transformative agreements on behalf of the universities and colleges

- Recommendations by the Swedish Government and the Swedish Research Council suggest that the transformation of OA to include all publicly funded research publications should be completed by 2026

- There are no OA book-specific funds in Sweden

- The OA book publishers Stockholm University Press and Kriterium play a pivotal role as library/scholar-led initiatives

- Libraries rely on aggregators for OA book coverage

\subsection{GENERAL LIBRARY SYSTEM FOR E-CONTENT AND OA PUBLICATIONS}

Research libraries in Sweden differ substantially when it comes to their size, resources and funding. The Bibsam consortium, with 55 participating institutions (as of 2019), is in charge of licence negotiations for e-content with international publishers on behalf of Swedish universities, university colleges, research institutes and governmental agencies (Bibsam Consortium, n.d.). 
The National Library of Sweden has since 2017 been acting as a national contact point with responsibility for coordinating and investigating work related to the aim of open access to research publications in Sweden (Koulocheri, n.d.). As part of this initiative, five national investigation studies have been conducted over the period of 2017-2018, looking into the implications of transition to open access, with one focusing specifically on open access to monographs (see the summary of the recommendations in the main report, 2020) and one focusing on technical and financial support for scholarly journals (which has been translated to English: Open Access, n.d.).

\subsection{LIBRARY COMMUNITY AND OPEN ACCESS}

The Swedish Library Association represents both organisations and individuals and their aim is to promote libraries and their work by reporting news and supporting the development of skills for librarians. While the association does not have an open science policy, it follows actions that its member libraries decide to take.

\section{3. ОА ВООК POLICIES}

Open access has been an important part of the conversation about the future of scholarly communication since 2006 in Sweden, when the National Library of Sweden started its work towards advancing OA. In 2015 the Proposal for National Guidelines for Open Access to Scientific Information, produced by the Swedish Research Council, laid out basic principles for OA in Sweden, recommending that all publicly funded publications (books included), art works and data that the research was based on should be made available open access without embargo periods from 2020 the latest, with the OA policy fully implemented by 2026 (Proposal for National Guidelines for Open Access to Scientific Information, 2015).

The Research Bill Collaborating for knowledge - for society's challenges and strengthened competitiveness, presented in 2016, displayed the vision for higher education institutions for the period of 2017-2020, with open access being one of the desirable directions (Regeringskansliet, 2016).

The general national approach is followed by universities and research institutes, with individual OA policies differing per institution. There are 12 institutional OA policies registered in the ROARmmap for Sweden, with two specifically mentioning books (Blekinge Institute of Technology and University College of Boras).

\subsection{OA BOOK FUNDING}

Funding for OA books in Sweden is generally provided as part of research grants, with no OA book-specific funds available on a national level. Individual institutions might have their own OA funds, geared mostly towards APCs.

Some Swedish research funders, such as Riksbankens Jubileumsfond, encourage researchers to submit applications for publishing costs including books, even if this is not included in the official policy. Others, like the Swedish Research Council, also mentions books in their open access policy, even if it is not a requirement (Publishing Your Research Open Access, n.d.). 


\subsection{LIBRARY/SCHOLAR-LED OA BOOK PUBLISHING}

Two main players in the field of library/scholar-led OA book initiatives in Sweden are Stockholm University Press and Kriterium, the first being a proper publishing house and the latter labelling itself as "a mark of quality".

Stockholm University Press publishes OA journals and books and is open to proposals from any author, not necessarily affiliated to Stockholm University. The press is run by the university library. Editorial Boards consisting of experts in the fields of humanities, social and natural sciences assess the academic quality of submitted proposals and they are also responsible for selecting reviewers for the external peer review process applied for all manuscripts. The Publishing Committee, consisting of representatives of four faculties of the Stockholm University, supervises the transparency and fairness of the peer review processes and makes final decisions concerning acceptance for publication. Stockholm University Press operates on a gold OA model, with a BPC charged to authors on a case-by-case basis, depending on the range of provided publishing services, with an approximate BPC at $£ 3,250$ (+VAT) for a book of about 200 pages. SUP's portfolio consists of 31 OA books and it runs 12 book series. The Editorial Boards consist of at least three to five experts in their respective field, where at least one member should be affiliated to Stockholm University.

Kriterium calls itself a "portal" for review rather than a publisher (Kriterium, n.d.). This initiative is a collaborative effort between universities and academic presses focused on publication of peer reviewed academic books, with a special emphasis on humanities, social sciences and Swedish scholarship. Kriterium takes care of the peer review process, while the production of books is carried out by participating publishers. The open access versions of the books are usually published via the Kriterium website and added to the OAPEN Library, while the print books are usually manufactured by the publisher of the book. The initiative is supported by the Swedish Research Council, the National Library of Sweden and the Riksbankens Jubileumsfond. Currently there are nine participating universities (Gothenburg University, Karlstad University, Lund University, Malmö University, Stockholm University, Södertörn University, Umeå University, Uppsala University and Örebro University) and two participating publishers (Nordic Academic Press and Makadam publishers).

Lund University Press is the body is led by a steering committee, consisting of representatives of the supporting institutions (SRC, NLS and RJ), of participating university libraries and publishing houses. They oversee the work of the consortium, proposing guidelines, while a group of academic co-ordinators gathered in the Editorial Board supervises the academic merit of the published content. So far, 21 OA books have been published with the Kriterium "mark of quality". Lund University Press has entered a collaboration with Manchester University Press, where the print books are available for purchase and the online versions are added to the Manchester Hive for additional distribution.

\subsection{INTEGRATION OF OA BOOKS IN LIBRARY SYSTEMS}

$\mathrm{OA}$ books are integrated with the general library discovery systems that rely on EBSCO services. In order to make sure that the users have access to OA books (as they are sometimes not fully covered by EBSCO) libraries add links to DOAB and OAPEN to facilitate browsing through a global OA books portfolio.

Many libraries use the DiVA repository, governed by a national consortium of libraries, to publish and disseminate locally produced books (and other types of publications such as reports, conference proceedings, local journals etc.). DiVA is usually the place where universities publish PhD theses, but it 
also serves as the main repository for green open access. The archive itself is free to access, but it is up to each contributor to indicate and manage rights for their publication. This means that content may or may not be classified as open access. However, for many libraries this is the only affordable option for them to support open publication.

In addition to that, SwePub, the national publication database, lists more than 25,000 open access books.

\section{Important contributors}

The National Library of Sweden https://www.kb.se/in-english.html

SUHF (The Association of Swedish Higher Education Institutions) https://suhf.se/in-english/

The Swedish Library Association https://www.biblioteksforeningen.se/in-english/

Bibsam Sweden https://www.kb.se/samverkan-och-utveckling/oppen-tillgang-och-bibsamkonsortiet/ open-access-and-bibsam-consortium/bibsam-consortium.html

Stockholm University Press https://www.stockholmuniversitypress.se

Kriterium https://www.kriterium.se/site/en-welcome/

Lund University Press https://wwwhttps://www.lunduniversitypress.lu.se/.lunduniversitypress.lu.se/

DIVA repository https://www.diva-portal.org/

SwePub http://swepub.kb.se

\section{THE NETHERLANDS}

\section{Key findings}

- The Netherlands, being a small country, enjoys close geographical proximity of libraries which form tight professional networks

- The National Open Science Plan was introduced in 2017 and it includes books

- There are OA book-specific funds, both on national funder and institutional levels

- There is a plethora of stakeholders engaged in the implementation of the National Open Science Plan: the UKB (The Dutch library consortium), VSNU (the Association of Universities in the Netherlands (VSNU) and the NWO (the National Research Foundation) and the NPOS (Netherlands Plan Open Science) being the crucial players for scholarly books output

- No typically scholar/library led OA book initiatives based on non-BPC models were identified

- Libraries rely on aggregators for OA book coverage 


\subsection{GENERAL LIBRARY SYSTEM FOR E-CONTENT AND OA PUBLICATIONS}

The Dutch higher education system comprises of public research universities and universities of applied sciences, as well as medical and private business schools. The Netherlands has been among the first European countries to support transition to open science, and academic libraries played a significant role in the development of OA on a national level. The UKB consortium, comprised of 13 Dutch research libraries, the Open University Library and the National Library of the Netherlands, represents the interests of its stakeholders (Leden | UKB, n.d.). In the 2017 document entitled The Power of Synergy. Ambitions 2017-2020, UKB identified five focus points for its activities, ranging from the library architecture requirements, creating and maintaining access to collections, supporting teaching stuff, students, and researchers to setting up joint systems (The Power of Synergy. Ambitions 20172020, 2017). UKB, together with VSNU (The Association of Universities in the Netherlands), is in charge of negotiating deals with large commercial publishers on a national level. Following the government's directives, the UKB and VSNU are making sure that no new deals are signed without an open access component.

\subsection{LIBRARIES AND OPEN ACCESS BOOKS}

The library community is OA-oriented and interconnected, with a strong presence of both formal (UKB) and less formal (mailing list) networks. Several working groups, comprised of librarians, operate within larger open science-related projects, sharing best practices and informing strategical decisions taken by each library. The UKB Open Access Working Group focuses specifically on all OA-related issues.

There are two main communication channels about OA geared towards the academic sector in the Netherlands: openaccess.nl provides information on current OA policies, OA-related projects and the advantages of OA, while the National Platform Open Science was set up to monitor developments in OS/OA on a European scale and share best practices.

\subsection{OA BOOK POLICIES}

In February 2017, following its 2016 EU presidency and strongly pushing towards OA on the European scale, the Netherlands released its National Open Science Plan. It called for open access, with no embargo periods, to all publicly funded scholarly publications (books included) to be achieved by 2020. The implementation of the National Plan was handed to the joint forces of VSNU, UKB and SURF (National Plan Open Science, 2017).

A recently established project $\mathrm{C} 1$ : Exploration of broadening Open Access to books is exploring the measurements to be taken and further policies to be implemented in order to increase the uptake of OA books (Project C1: Verkenning Verbreding Open Access Naar Boeken, n.d.).

The Dutch Research Council (NWO) has also mandated OA on publications funded by their grants for journals, book chapters and books.

Most Dutch HEls have created their own institutional OA policies. Currently, there are $11 \mathrm{HEls}$ listed in the ROAR map with OA policies. Among them, however, only four specifically mention books (Radboud University, Royal Netherlands Academy of Arts and Sciences, Tilburg University and Wageningen University). All HEI repositories are aggregated in www.narcis.nl. 


\subsection{OA ВОOK FUNDING}

There are OA book-specific funds in the Netherlands, on both the funder and institutional levels.

NWO has recently launched a funding scheme dedicated specifically to BPC payments for OA monographs resulting from NWO funding. The fund amounts to up to 10,000 EUR per book and makes it clear that it is for monographs only, excluding other types of book-form publications such as trade books, conference proceedings, textbooks and dissertations (Open Access Books | NWO, n.d.).

Dutch researchers at the TU Delft and Utrecht University can also take advantage of institutional funds, which cover both APCs and BPCs. They come with a funding cap (at Utrecht University $50 \%$ of BPCs are reimbursed with a maximum of cap at 2,500 EUR, while TU Delft put its cap at 4,500 EUR per book) (Open Access Fund - Utrecht University Library - Universiteit Utrecht, n.d.; Open Access Funding, n.d.).

\subsection{LIBRARY/SCHOLAR-LED OA BOOK PUBLISHING}

Alongside university presses - such as Amsterdam University Press, with its long tradition of OA book publication - there are institutions offering publishing services to their authors. Among them TU Delft provides its researchers with an option of publishing OA books under its imprint BK Books, associated with the Faculty of Architecture and Build Environment. Publishing services are reserved for the TU Delft affiliates; the press operates on a BPC model. BK Books operates on Open Monographs Press software and releases books in PDF format (BK BOOKS, n.d.).

As of 2019, University of Groningen Press offers a platform for affiliated researchers, where they can publish academic books in open access. The press runs on Open Monograph Press with books available as PDF files (Books and Series, 2019).

Among scholar-led presses one notices Open Press TiU, associated with the Tilburg University, which aims to publish $100 \%$ of their books OA. The press charges "affordable and transparent book processing charges" to authors (Open Press | Openpresstiu, n.d.).

No OA book publishing initiatives operating on a BPC-alternative model were found.

\subsection{INTEGRATION OF OA BOOKS IN LIBRARY SYSTEMS}

Open access books are integrated with the discovery tools and library catalogues in The Netherlands. For this inclusion they rely on the service providers, without taking additional measures to list DOAB for a list of open access books available.

\section{Important contributors}

UKB https://www.ukb.nl/english

The National Research Organisation (NWO) https://www.nwo.nl/en

VSNU https://www.vsnu.nl/en GB

openaccess.nl https://www.openaccess.nl/en

National Platform Open Science https://www.openscience.nl/en

SURF https://www.surf.nl/en

University of Groningen Press https://www.rug.nl/library/ugp/about

TU Delft Open https://books.bk.tudelft.nl/index.php/press/open 
OAPEN https://www.oapen.org

U of Amsterdam https://www.aup.nl/en/publish/open-access

Open Press TiU

https://www.tilburguniversity.edu/research/open-science-community/open-press-tiu 


\section{REFERENCES}

Ferwerda, E., Pinter, F., \& Stern, N. (2017). A Landscape Study on Open Access and Monographs: Policies, Funding and Publishing in Eight European Countries. Zenodo. https://doi.org/10.5281/ zenodo.815932

SPARC Europe, \& Digital Curation Centre. (2019). An Analysis of Open Science Policies in Europe v4. Zenodo. https://doi.org/10.5281/ZENODO.3379705

Penier, Izabella, Eve, Martin Paul, \& Grady, Tom. (2020, September 7). COPIM - Revenue Models for Open Access Monographs 2020 (Version 1.0). Zenodo. http://doi.org/10.5281/zenodo.4011836

\section{CROATIA}

What is DABAR? / Digital Academic Archives and Repositories. Retrieved December 3, 2020, from https://dabar.srce.hr/en/dabar

Declaration - Open Access - otvoreni pristup znanstvenim informacijama. Retrieved December 3, 2020, from https://www.fer.unizg.hr/oa2012/declaration\#

Strategy for Education, Science and Technology (2017) https://mzo.gov.hr/UserDocs/mages/ dokumenti/Obrazovanje/Strategy\%20for\%20Education,\%20Science\%20and\%20Tehnology.pdf

Vrednovanje znanstveno-istraživačkog rada i promicanje otvorenog pristupa znanstvenim informacijama i istraživačkim podacima. (2015). Croatian Rectors Conference. http://www. rektorski-zbor.hr/fileadmin/rektorat/O Sveucilistu/Tijela sluzbe/Rektorski zbor/dokumenti2/ Vrednovanje znanstvenog rada i otvoreni pristup znanstvenim informacijama Rektorski zbor. $\underline{\mathrm{pdf}}$

Upisnik knjižnica Upisnik knjižnica u Republici Hrvatskoj. (n.d.). Retrieved December 15, 2020, from http://upisnik.nsk.hr/upisnik-knjiznica/

O HED biblioteci - hrvatsko etnološko društvo. (n.d.). Retrieved December 15, 2020, from https:// hrvatskoetnoloskodrustvo.hr/o-hed-biblioteci/

MorePress. (n.d.). Retrieved December 15, 2020, from https://morepress.unizd.hr/index en.php

Croatian Research and Innovation Infrastructures Roadmap 2014-2020 | RIO - H2020

PSF. (n.d.). Retrieved December 15, 2020, from https://rio.jrc.ec.europa.eu/library/

croatian-research-and-innovation-infrastructures-roadmap-2014-2020

Vrednovanje znanstveno-istraživačkog rada i promicanje otvorenog pristupa znanstvenim informacijama i istraživačkim podacima. (n.d.). http://www.rektorski-zbor.hr/fileadmin/ rektorat/O Sveucilistu/Tijela sluzbe/Rektorski zbor/dokumenti2/Vrednovanje znanstvenog rada i otvoreni pristup znanstvenim informacijama Rektorski zbor.pdf

Zakon o znanstvenoj djelatnosti i visokom obrazovanju - Zakon.hr. (n.d.). Retrieved December 15, 2020, from https://www.zakon.hr/z/320/Zakon-o-znanstvenoj-djelatnosti-i-visokom-obrazovanju

\section{DENMARK}

Quick, Mona. (2004). Library consortiums in the Nordic countries. Scandinavian Library Quarterly, 37(4). http://slq.nu/index89fe.html?article=library-consortiums-in-the-nordic-countries 
Denmark's National Strategy for Open Access. (2018). https://ufm.dk/en/research-and-innovation/ cooperation-between-research-and-innovation/open-access/Publications/denmarks-nationalstrategy-for-open-access/national-strategy-for-open-access-english.pdf

Governance structure for national licence negotiations in Denmark. (n.d.). https://kub.kb.dk/ Id.php?content id=32749400

Rapport med anbefalinger fra arbejdsgruppen om den fremtidige organisering af forskningsbiblioteksområdet. (n.d.). https://kum.dk/fileadmin/KUM/Documents/Nyheder\%20 og\%20Presse/Nyheder/2018/Rapport med anbefalinger fra arbejdsgruppen om forskningsbiblioteker.pdf

Licensforhandlinger skal samles på Det Kgl. Bibliotek. (n.d.). Retrieved December 3, 2020, from https://kum.dk/aktuelt/nyheder/licensforhandlinger-skal-samles-paa-det-kgl-bibliotek

Danmark får et samlet Nationalbibliotek - Det Kgl. Bibliotek. (n.d.). Retrieved December 3, 2020, from https://www.statsbiblioteket.dk/om-statsbiblioteket/danmark-far-et-samlet-nationalbibliotek

Beagrie, Charles. (2014). Permanent Access to e-Journals in Denmark. https://www.deff.dk/fileadmin/ user upload/DEFF/publikationer/Oevrige/Permanent Access to e-Journals in Denmark.pdf

Forside. (n.d.). Danske Universiteter. Retrieved December 3, 2020, from https://dkuni.dk/

Nationalt licenskonsortium. (n.d.). Det Kgl. Bibliotek.

Open Access Fund. (n.d.). SDU. Retrieved December 8, 2020, from https://www.sdu.dk/en/forskning/ forskningspublicering/open+access/open+access+fond

\section{FINLAND}

DECLARATION FOR OPEN SCIENCE AND RESEARCH (FINLAND) 2020-2025. (2019). https://avointiede.fi/ sites/default/files/2020-02/declaration2020 0.pdf

Academy of Finland - Academy of Finland. (n.d.). Retrieved December 8, 2020, from https://www.aka. fi/en/

In Finland LIBRARIES basic service for everyone. (n.d.). https://www.libraries.fi/sites/default/files/ content/service-for-everyone-public-libraries-in-finland-2020.pdf

Open Access to Scholarly Publications National Policy Executive Plan by the Research Community in Finland for 2020-2025. (2019). https://avointiede.fi/sites/default/files/2020-03/openaccess2019. pdf

Open Access to Scholarly Publications National Policy Executive Plan by the Research Community in Finland for the Finnish Scholarly Community. (2018). https://www.unifi.fi/wp-content/ uploads/2019/04/UNIFI Open Science and Data Action Programme.pdf

Strategic Plan of the National Library of Finland 2021-2030. (2020). https://www.doria.fi/bitstream/ handle/10024/177161/Kansalliskirjaston strategia 2021-2030 en.pdf?sequence=1\&isAllowed=y

Higher education institutions and science agencies. (n.d.). Opetus- Ja Kulttuuriministeriö. Retrieved December 8, 2020, from https://minedu.fi/en/heis-and-science-agencies

Kirjastokonsortio Aleksandria - suomalainen tiedekirjallisuus avoimeksi verkkoon. (n.d.). Suomalaisen Kirjallisuuden Seura. Retrieved January 22, 2021, from https://www.finlit.fi/fi/ kirjastokonsortio-aleksandria-suomalainen-tiedekirjallisuus-avoimeksi-verkkoon 
Information for authors / Tampere universities. (n.d.). Retrieved December 9, 2020, from https://www. tuni.fi/en/library/study-and-research/tampere-university-press/information-for-the-authors

Helsinki University Press. (n.d.). Retrieved December 9, 2020, from https://hup.fi/site/about/

FRANCE

Liste des membres - Membres. (n.d.). Retrieved December 3, 2020, from https://www.couperin.org/ presentation/membres

National Plan for Open Science. (2018). https://cache.media.enseignementsup-recherche.gouv.fr/file/ Recherche/50/1/SO A4 2018 EN 01 leger 982501.pdf

ABES. Projet d'établissement ABES 2018-2022. https://abes.fr/wp-content/uploads/2019/07/projetetablissement-abes-2018-2022.pdf

Jussieu Call. (n.d.). Retrieved January 5, 2021, from https://jussieucall.org/jussieu-call/

Ouvrir la Science - The Committee for Open Science. (n.d.). Retrieved January 8, 2021, from https:// www.ouvrirlascience.fr/the-committee-for-open-science/

Swiatek, C. (2020, March 20). ADBU: Qui sommes-nous ? / About us. ADBU-Association des directeurs et des personnels de direction des bibliothèques universitaires. https://adbu.fr/about/

\section{GERMANY}

Higher Education System. (n.d.). Retrieved December 3, 2020, from https://www.hrk.de/activities/ higher-education-system/

BMBF / FMER. (2016). Open Access in Deutschland Die Strategie des Bundesministeriums für Bildung und Forschung. https://www.bmbf.de/upload filestore/pub/Open Access in Deutschland.pdf

DINI - Project details. (n.d.). Retrieved December 10, 2020, from https://www.sub.uni-goettingen.de/ en/projects-research/project-details/projekt/dini/

Berlin Declaration. (n.d.). Retrieved January 8, 2021, from https://openaccess.mpg.de/ Berlin-Declaration

Nordhoff, Sebastian. (2018). Language Science Press business model. Language Science Press. https:// zenodo.org/record/1286972\#.X6WMRi2ZOu4

GREECE

Hellenic Academic Libraries Link. Declaration on Open Access in Greece. https://www.heal-link.gr/ librarians files/other/Declaration\%20on\%200pen\%20Access\%20in\%20Greece.pdf

SELL statement on Open Access. (2018). https://www.heal-link.gr/SELL/wp-content/uploads/2018/06/ SELL Thessaloniki statement may 2018.pdf

Project Kallipos - Open Educational Resources. (n.d.). Retrieved December 3, 2020, from https://www. kallipos.gr/en/component/k2/itemlist/tag/Open\%20Educational\%20Resources.html 
ITALY

Legge n. 112/2013. (n.d.). Retrieved December 3, 2020, from https://www.bosettiegatti.eu/info/ norme/statali/2013 0112.htm

Mission - CRUI - Conferenza dei Rettori delle Università italiane. (n.d.). Retrieved December 3, 2020, from https://www.crui.it/mission.html

Revenue sources and publication charge policy. (n.d.). Retrieved December 3, 2020, from https:// fupress.com/revenue-sources-and-publication-charge-policy

NORWAY

Frantsvåg, J. E. (2008). Open Access in Norway - Where are we and where are we going? ScieCom Info, 4(1). https://journals.lub.lu.se/sciecominfo/article/view/244

National strategy on access to and sharing of research data. https://www.regieringen.no/contentasset s/3a0ceeaa1c9b4611a1b86fc5616abde7/en-gb/pdfs/national-strategy-on-access summary.pdf

National goals and guidelines for open access to research articles. (2017). https://www.regjeringen. no/contentassets/ae7f1c4b97d34806b37dc767be1fce76/national-goals-and-guidelines-for-openaccess-to-research-articles.pdf

Expression of support for a common negotiating strategy for open access to research articles. (2018). https://www.ceres.no/tjenester/laat/english/expression-of-support-for-a-common-negotiatingstrategy-for-open-access-to-research-articles $\% 2867832 \% 29-\% 28002 \% 29 . p d f$

Action Plan for Digitalisation in Higher Education and Research. (2019). https://www.unit.no/sites/ default/files/media/filer/2019/07/The-Action-Plan-for-digitalisation.pdf

Open access to publications. (n.d.). Retrieved December 3, 2020, from https://www.forskningsradet. no/en/Adviser-research-policy/open-science/apen-tilgang-til-publikasjoner/

Publiseringsfond ved norske UH-institusjonar - frontpage. (n.d.). Retrieved December 3, 2020, from https://www.openaccess.no/Finansiering/publiseringsfond/index.html

POLAND

Wprowadzenie polityki otwartego dostępu do publikacji powstałych w projektach badawczych / Narodowe Centrum Nauki. Retrieved December 3, 2020, from https://ncn.gov.pl/ aktualnosci/2020-02-27-plany-ncn-otwarty-dostep

Niezgodka, M. (2011). Wdrozenie i promocja otwartego dostępu do treści naukowych i edukacyjnych. https://depot.ceon.pl/bitstream/handle/123456789/1545/20120208 EKSPERTYZA OA ICM. pdf? sequence $=1$ \&isAllowed $=\mathrm{y}$

Fenrich, W., Siewicz, K., \& Szprot, J. (2016). Towards Open Research Data in Poland. http://pon.edu.pl/ nasze-publikacje?pubid=19

Kulczycki, E. (2018). The diversity of monographs: changing landscape of book evaluation in Poland. Aslib Journal of Information Management, 70(6), 608-622. https://doi.org/10.1108/ AJIM-03-2018-0062 
Raport nt. realizacji polityki otwartego dostępu do publikacji naukowych w latach 2015-2017. (2018). https://www.gov.pl/attachment/39be7405-7ba5-460e-9a66-56487dd05fe2

Szprot, J. (n.d.). Otwarty dostęp w instytucjach naukowych. http://pon.edu.pl/ nasze-publikacje?pubid $=17$

Siewicz, K. (n.d.). Otwarty dostęp do publikacji naukowych - kwestie prawne. http://pon.edu.pl/ nasze-publikacje?pubid $=12$

Szprot, J. (2014). Open Science in Poland 2014. A Diagnosis. http://pon.edu.pl/ nasze-publikacje?pubid $=16$

PORTUGAL

Finanças, Cultura e Ciência, Tecnologia e Ensino Superior. (2016). Diário da República, 2.a série - N.o 244. https://dre.pt/application/conteudo/105594707

Segundo Relatório da Comissão Executive do Grupo de Trabalho Para A Política Nacional de Ciência Aberta. (2016). Comissão Executiva GT-PNCA. http://docs.wixstatic.com/ugd/a8bd7c 3274046fc8c e42c78db2ec1707c0a0fd.pdf

\section{SLOVENIA}

Akcijski Načrt Izvedbe Nacionalne Strategije Odprtega Dostopa Do Znastvenih Objav In Raziskovalnih Podatkov v Sloveniji 2015-2020. (2017). https://www.gov.si/assets/ministrstva/MIZS/Dokumenti/ ZNANOST/Strategije/Akcijski-nacrt-izvedbe-nacionalne-strategije-odprtega-dostopa-doznanstvenih-objav-in-raziskovalnih-podatkov-v-Sloveniji-2015-2020.pdf

Ambrožič, M., \& Žumer, M. (2015). Libraries and the Library System of Slovenia. LIBRARY TRENDS, 63(4), 725-744. https://core.ac.uk/download/pdf/158312962.pdf

Research Infrastructure Roadmap 2011-2020. Revision 2016. (2016). https://www.gov.si/assets/ ministrstva/MIZS/Dokumenti/ZNANOST/Strategije/Research-Infrastructure-Roadmap-2011-2020Revision-2016-ENG.pdf

SPAIN

Ley 14/2011, de 1 de junio, de la Ciencia, la Tecnología y la Innovación. (2011). https://www.boe.es/ buscar/pdf/2011/BOE-A-2011-9617-consolidado.pdf

Spanish National Plan For Scientific and Technical Research and Innovation. (2013). https://www. ciencia.gob.es/stfIs/MICINN/Investigacion/FICHEROS/Spanish RDTI Plan 2013-2016.pdf

Plan Estatal de Investigación Científica y Técnica y de Innovación. (2017). https://www.ciencia.gob.es/ stfIs/MICINN/Prensa/FICHEROS/2018/PlanEstatalIDI.pdf

Repositorios / Red de Biblioteca Universitarias Españolas. (n.d.). Retrieved December 8, 2020, from https://www.rebiun.org/grupos-trabajo/repositorios

Registro de Universidades, Centros y Títulos. (2020). https://www.educacion.gob.es/ruct/ listauniversidades?tipo univ $=\& d-8320336-p=1 \& c c c a a=\& a c t u a l=u n i v e r s i d a d e s \& c o n s u l t a=1 \&$ codigo Universidad $=$ 
Echeverría, M. and Jiménez, S. (2011), Interlending and document supply in the context of Spanish library consortia, Interlending \& Document Supply, Vol. 39 No. 4, pp. 190-199. https://doi. org/10.1108/02641611111187613

\section{SWEDEN}

National Library of Sweden. (2020). The transition to an open access scholarly publishing system. https://www.kb.se/samverkan-och-utveckling/oppen-tillgang-och-bibsamkonsortiet/open-accessand-bibsam-consortium/open-access.html

Proposal for national guidelines for open access to scientific information. (2015). https://www.vr.se/ download/18.2412c5311624176023d25590/1555426972107/Proposal-nat-guidelines-openaccess VR 2015.pdf

Expenditure on scholarly publishing Universities and University Colleges 2017. (n.d.). https://www. kb.se/samverkan-och-utveckling/oppen-tillgang-och-bibsamkonsortiet/open-access-and-bibsamconsortium/open-access.html

Bibsam Consortium. Retrieved December 3, 2020, from https://www.kb.se/samverkan-och-utveckling/ oppen-tillgang-och-bibsamkonsortiet/open-access-and-bibsam-consortium/bibsam-consortium. $\underline{\text { html }}$

Regeringskansliet, R. och. (2016, November 28). Collaborating for knowledge - for society's challenges and strengthened competitiveness [Text]. Regeringskansliet. https://www.government.se/press-releases/2016/11/ collaborating-for-knowledge--for-societys-challenges-and-strengthened-competitiveness/

Koulocheri, E. (n.d.). Sweden. OpenAIRE. Retrieved December 17, 2020, from https://www.openaire. eu/os-sweden

Open Access. (n.d.). https://www.kb.se/samverkan-och-utveckling/oppen-tillgang-ochbibsamkonsortiet/open-access-and-bibsam-consortium/open-access.html

Publishing your research open access. (n.d.). Retrieved December 17, 2020, from https://www.vr.se/ english/applying-for-funding/requirements-terms-and-conditions/publishing-open-access.html

Kriterium. (n.d.). Retrieved December 17, 2020, from https://www.kriterium.se/site/en-about/

\section{THE NETHERLANDS}

National Plan Open Science. (2017). https://www.openscience.nl/files/openscience/2019-02/ nationalplanopenscience en.pdf

The Power of Synergy. Ambitions 2017-2020. (2017). https://bluesyemre.files.wordpress. com/2017/06/power-of-synergy-ukb-ambitions-2017-2020-website-version.pdf

Leden / UKB. (n.d.). Retrieved December 9, 2020, from https://www.ukb.nl/leden

Project C1: Verkenning verbreding Open Access naar boeken. (n.d.). Retrieved December 9, 2020, from https://www.openscience.nl/projecten/ project-c1-verkenning-verbreding-open-access-naar-boeken

Open Press / openpresstiu. (n.d.). Retrieved December 9, 2020, from https://www.openpresstiu.org/ open-press 
Open Access Books / NWO. (n.d.). Retrieved December 9, 2020, from https://www.nwo.nl/en/calls/ open-access-books

Open Access Fund - Utrecht University Library - Universiteit Utrecht. (n.d.). Retrieved January 22, 2021, from https://www.uu.nl/en/university-library/advice-support-for/researchers/open-access/ are-there-any-costs/open-access-fund

Open Access Funding. (n.d.). TU Delft. Retrieved January 22, 2021, from https://www.tudelft.nl/en/ library/library-for-researchers/library-for-researchers/publishing-outreach/open-access-funding BK BOOKS. (n.d.). Retrieved January 22, 2021, from https://books.bk.tudelft.nl/index.php/press Books and series. (2019, April 4). University of Groningen. https://www.rug.nl/library/ugp/ books-and-series 


\section{APPENDICES}

\section{General interview questions for librarians}

Aim: to get a sense of a general library landscape per country, to understand each country library systems' intricacies and to point out main common points and differences between them within the European context.

Based on answers to the general interviews, a set of follow-up questions will be put together, with specific issues touched upon in each country.

Name:

Position:

University:

\section{General structure}

1. What are the main characteristics of the library system in your country?

2. Are there any library consortia in your country and if so could you briefly explain how they are organised? Is your institution part of them?

3. Who, within the library structure, is responsible for open access publications? Who are the main decision makers in that area?

\section{Library community per country}

4. Are there any open access-specific projects, associations or working groups among librarians in your country?

5. What are the main library networks, journals, communication channels that you use among librarians in your country?

\section{Open access books}

6. Does your library have an open access policy? If so, could you describe how it works? Does it include books? (if there is no OA policy in place: What are the reasons for your institution not to have an OA policy? What would you find helpful in the process of developing such policy?).

6a. *** How representative is your institution of the wider national library landscape when it comes to this topic: is the set-up you described "typical" for libraries in your country or are there differences between libraries?

7. How do you fund open access books? Do you have a specific budget allocated towards open access publications? (if there is no OA fund: What are the reasons for your institution not to support OA books?) 
7a. ${ }^{* * *}$ How representative is your institution of the wider national library landscape when it comes to this topic: is the set-up you described "typical" for libraries in your country or are there differences between libraries?

8. If you fund BPCs, do you have a cap up to which you will fund an open access book? How do you determine such a cap?

$8 a{ }^{* * *}$ How representative your is institution of the wider national library landscape when it comes to this topic: is the set-up you described "typical" for libraries in your country or are there differences between libraries?

9. What would you require to justify expenditure on OA content to internal budget managers and decision makers?

10. Are you legally able to support third party OA publishers/platforms without receiving specific products or services in return?

10a. ${ }^{* * *}$ How representative your is institution of the wider national library landscape when it comes to this topic: is the set-up you described "typical" for libraries in your country or are there differences between libraries?

11. Are you, as a library, looking to publish OA books yourselves (e.g. thesis, faculty/scholarly-led publishing initiatives)? If there are no initiatives like that in the library itself, are there any scholarly groups within your institution who are looking into that?

$11 a{ }^{* * *}$ How representative your is institution of the wider national library landscape when it comes to this topic: is the set-up you described "typical" for libraries in your country or are there differences between libraries?

12. Are there general national-level initiatives in your country that encourage library/scholar-led OA book publishing initiatives?

13. What discovery systems are used for open access books in your country? Do they differ from discovery systems used for closed content?

13a.*** How representative your is institution of the wider national library landscape when it comes to this topic: is the set-up you described "typical" for libraries in your country or are there differences between libraries?

\section{Further steps}

Would you be willing to act as our national contact point for further inquiries and preparation of regional events, such as workshops for librarians? 


\section{Pre-workshops survey questions}

\section{SECTION 1: GENERAL}

1. Please identify your role within an institutional library and provide a sense of how you and/or your institution facilitates support for open access (in general).

2. What are the major inefficiencies or roadblocks that you experience in that process?

\section{SECTION 2: OPEN ACCESS BOOKS}

3. Does your library presently support Open Access book publishing initiatives? If so, which ones? (you can simply list these - we will be asking for views on some different initiatives later in the survey)

4. What are the most significant challenges that you/your institution encounters in supporting Open Access books / Open Access book publishing?

5. What are the critical pieces of information for you/your institution in deciding to support, or not support, an Open Access book publishing initiative?

\section{SECTION 3: OPEN ACCESS INITIATIVES}

6. Knowledge Unlatched's KU Select programme: https://www.knowledgeunlatched.org/ku-selectlibrary-info/ What are the positives and/or negatives from your/your institution's perspective?

7. Knowledge Unlatched's Open Research Library: https://www.knowledgeunlatched.org/openresearchlibrary/ What are the positives and/or negatives from your/your institution's perspective?

8. OpenEdition https://www.openedition.org/8851 What are the positives and/or negatives from your/your institution's perspective?

9. Open Book Publishers' Library Membership Programme: https://www.openbookpublishers.com/ section/44/1 What are the positives and/or negatives from your/your institution's perspective?

10. Open Library of Humanities Library Partnership Subsidy Model: https://www.openlibhums.org/ site/about/the-olh-model/ What are the positives and/or negatives from your/your institution's perspective?

11. Are there any other specific Open Access initiatives, in particular those designed to support Open Access books, that you would like to offer feedback on?

\section{SECTION 4: NEW INFRASTRUCTURES}

How might the following influence you/your institution's decision to support such an infrastructure (please rate on a scale: much less likely to support, slightly less likely to support, neither more nor less likely to support, slightly more likely too support, much more likely to support):

a. If the infrastructure is non-commercial

b. If the infrastructure is developed according to the principles of Open Source Software

c. If your institution has some ownership/control over the infrastructure provided

d. If your institution has control over which specific projects/publishers your institution financially supports

e. If access to specific projects/publishers is determined via a centralised / collective funding decision making process

f. If the infrastructure is community-led or governed 
For those factors that make it "much more likely" for you/your institution to support such an infrastructure, could you explain why? (If none are 'much more likely' please explain why for those that are 'slightly more likely').

Are there any other factors might influence you/your institution's choice to support such an infrastructure? If so, what are they? Why are they important?

Do you have any other comments you'd like to add? 